\title{
Bizans Dönemi Taş Eserlerinde Refrigerium Sahneleri ${ }^{1}$
}

\author{
Tuğçe KARADEMİ*
}

ÖZET

Roma döneminde yemek sahneleri olarak tasvir edilen refrigerium sahneleri, Bizans sanatında freskolarda, mozaiklerde ve taş eserlerde, çoğunlukla bir kantharostan su içen tavus kuşu sahnelerine dönüşmüştür. Ancak, sahnenin merkezinde yer alan kantharos yerine kimi zaman bir çeşme veya hayat ağacı kimi zaman da haç ya da christogram geldiği görülür. Refrigerium teriminin Türkçe'de tam bir karşılığı yoktur. Hıristiyanlığın erken döneminde, hem ölen kişinin anısına mezarlığın yakınında kutlanan ziyafet hem de ölünün manevi rahatlığını ifade eden ferahlık anlamında kullanıldığı söylenebilir. Bizans dönemi taş eserleri üzerinde görülen refrigerium sahneleri incelenirken bu sahnelerin Huristiyan ikonografisi içerisindeki yerinin belirlenmesi amaçlanmıştır. Bu amaca yönelik çalışmalarımızda, refrigerium sahnesi içeren, Erken ve Orta Bizans dönemine ait farklı eser türlerinde toplam 32 tane taş eser tespit edilmiştir. Refrigerium sahnelerini incelerken, yaygın bir şekilde tavus kuşlarıyla gösterilen bu sahnelerin, ayrıca saflı̆̆ı ve masumiyeti sembolize eden güvercin figürü, "kanatlı ruhun" sembolü olarak kullanılan kuş figürü, yenilenme ve vaftizle ilişkili olan geyik figürü ile de kullanılmış olduğu tespit edilmiştir.

\section{Araştırma Makalesi}

Geliş: 24.07.2020

Kabul: 02.01.2021

Anahtar Kelimeler:

Refrigerium,

Tavus kuşu,

Taş eser,

Erken Hiristiyan sanatı

\section{Refrigerium Scenes in Byzantine Stone Works}

\section{ABSTRACT}

The representations of refrigerium, depicted as portrayal of food during the Roman period, were transformed into portrayal of peacocks drinking water from a kantharos in frescoes, mosaics and stone artifacts in Byzantine art. However, instead of the kantharos in the center of the representation, sometimes a fountain or a tree of life, and sometimes a cross or christogram can also appear. The term refrigerium is not an exact term in Turkish. It can be said that in the early period of Christianity, it was used both in the sense of the feast celebrated near the cemetery in memory of the deceased and the relief of the spiritual comfort of the dead. While examining the refrigerium scenes seen on Byzantine stone works, it is aimed to determine the significance of these representations in Christian iconography. For this purpose, a total of 32 stone artifacts with refrigerium portrayal, belonging to the early and middle Byzantine period, were identified. With examination of the representations, it was found that the refrigerium portrayal, which were commonly shown with peacocks, were also used with the pigeon figure symbolizing purity and innocence, the bird figure used as the symbol of "winged soul" and the deer figure associated with renewal and baptism.
Research Article

Received: 24.07.2020

Accepted: 02.01.2021

Keywords:

Refrigerium,

Peacocks,

Stone works,

Early christian art

${ }^{1}$ Bu çalışma, 2019 yılında Çanakkale Onsekiz Mart Üniversitesi Sosyal Bilimler Enstitüsü Sanat Tarihi Anabilim dalında yapılan Yüksek Lisans tezinden üretilmiştir.

* Çanakkale Onsekiz Mart Üniversitesi, Sosyal Bilimler Enstitüsü Sanat Tarihi Anabilim Dalı, tugcekrdmr246@gmail.com, ORCID ID: https://orcid.org/0000-0002-7135-6878 


\section{GíRíş}

Bizans sanatında freskolarda, mozaiklerde ve taş eserlerde bazen hayat ağacının ya da haç motifinin iki yanında duran bazen de bir çeşmeden ya da kantharostan su içen tavus kuşlarının bulunduğu sahnelere sıklıkla rastlanır. Tavus kuşu, etinin geç çürümesinden dolayı Antik çağlarda ölümsüzlüğün simgesi olarak görülmüştür ${ }^{2}$. Bu ölümsüzlük simgesinin yanı sıra Klasik Yunan mitolojisinde, Tanrıça Hera'nın simgesi olarak geçmektedir ${ }^{3}$. Romalılarda ise, ölen İmparatoriçelerin ruhlarını tanrılara taşıyan kutsal kuş olarak kabul edilir ayrıca Roma villalarının bahçelerinde bulunması ve mezar anıtlarının duvarlarına tavus kuşları resimlerinin yapılması soyluluk belirtisi olarak karşımıza çıkar ${ }^{4}$. Erken Hıristiyan sanatında ise, tavus kuşu ruhun ölümsüzlüğünü simgeleyen dinsel bir içeriğe dönüşerek cennet bahçesinde karşılıklı olarak bir su kaynağından su içen tavus kuşu kompozisyonları olarak görülür ve çeşitlemeleriyle kullanılır5.

Refrigerium olarak adlandırılan bu sahneler, aynı zamanda güzellik, iyi ruhlar, günahlardan arınma ve yeniden doğuş gibi sembolik anlamları da içerir 6 . Çalışmamızda, ulaşılabilen yayınlar yoluyla elde ettiğimiz Bizans dönemi taş eserleri üzerinde görülen refrigerium sahnelerinin kompozisyon özellikleri ile değerlendirilmesi ve Hıristiyan ikonografisi içerisindeki yerinin belirlenmesi amaçlanmıştır. Seçilen örnekler iyi durumda korunmuş, kompozisyonların tam olarak izlenebildiği ve farklı taş eser türlerine göre belirlenmiş olup, kompozisyonun merkezinde bulunan motifler temel alınarak gruplandırılmıştır.

\section{Bizans Dönemi Taş Eserlerinde Refrigerium Sahneleri}

Bizans taş eserlerinde bu kompozisyonu üç farklı biçimde görmek mümkündür ${ }^{7}$. Birinci gruptaki örneklerde kompozisyonun merkezinde yer alan ve kantharos olarak tanımlanan bir kabın iki yanına yerleştirilmiş tavus kuşları yer alır. Ravenna St. Appolinare Nuovo Bazilikası'nda bulunan 6. yüzyıla tarihlenen altar levhasında ${ }^{8}$ simetrik olarak yerleştirilmiş tavus kuşları, arka planı dolduran asma dallarına basmaktadır (Resim 1). Berlin Bode Müzesi'nde bulunan 6. yüzyıla ait korkuluk levhasında ${ }^{9}$

\footnotetext{
2 Ebru Parman, "Bizans Sanatında Tavus kuşu İkonografisi”, Sanat Tarihinde İkonografik Araştırmalar Güner İnal'a Armağan, Ankara, 1993, s.387.

${ }^{3}$ Azra Erhat, Mitoloji Sözlüğü, İstanbul, 2003, s.54. Ayrıca bkz: Stephen P. Kershaw, Yunan Mitolojisi Rehber Kitab1, çev. Şefik Turan, İstanbul, 2018, s.163.

${ }^{4}$ Ebru Parman, a.g.m. s.387.

5 a.g.m. s.388.

${ }^{6}$ a.g.m. s.391.

${ }^{7} \mathrm{Bu}$ amaca yönelik çalışmamızda yayınlar yoluyla ulaşılan otuz iki taş eser değerlendirmeye alınmıştır.

8 a.g.m. s.397.

${ }^{9}$ a.g.m, s.398.
} 
ve Venedik, St. Maria Assunta Kilisesi 11. yüzyıla ait ikonostasis levhasında ${ }^{10}$ da bu kompozisyonun benzer örnekleri görülür (Resim 2-3).

Bu gruba ait olan eserlerden Ravenna St. Appolinare Nuovo Bazilikası'nın 6. yüzyıla tarihlenen lahit kapağında ${ }^{11}$ simetrik düzende yerleştirilen tavus kuşları zemine basmaktadır ve kantharostan çıkan üzüm salkımlarını gagalar şekilde tasvir edilmişlerdir (Resim 4). İzmir Arkeoloji Müze bahçesinde bulunan 6-7. yüzyıllara tarihlenen levhada ${ }^{12}$ simetrik olan tavus kuşlarının ayakları havada duruyor izlenimi verir (Resim 5). Konya Arkeoloji Müzesi'nde yer alan 5-6. yüzyıllara ait kemer ${ }^{13}$, üzerindeki simetrik düzendeki tavus kuşları ise, zemine parmak uçlarıyla dokunurlar (Resim 6). Bu kompozisyonun benzer örneklerini Sakarya Arkeoloji Müzesi’nde bulunan Erken Bizans dönemine ait levhada, İtalya Pavia Müzesi'nde yer alan ve 8. yüzyıla tarihlenen lahit teknesinde ${ }^{14}$, Konya Ilgın, Beykonak Köyü, Dediği Mahmut Sultan Mescidi'nin giriş kısmında 11. yüzyıla tarihlenen levhada ${ }^{15}$ ve Çanakkale, Ayvacık, Tuzla Hüdavendigar Cami duvarında devşirme malzeme olarak kullanılan Orta Bizans dönemine ait arşitravda ${ }^{16}$ görmek mümkündür (Resim 7-10). Kuşadası Kadıkalesi kazısında bulunan levhada ${ }^{17}$ simetrik düzendeki tavus kuşları kompozisyon alanına sı̆̆gırılabilmek için kuyrukları gövdelerine doğru kıvrılmış şekilde gösterilmiştir (Resim 11). Diğerlerinden farklı olarak ayakları, merkezde yer alan kabın kaidesindedir. Konya Arkeoloji Müzesi'nde bulunan 5-6. yüzyıllara ait levhadaki ${ }^{18}$ simetrik bir düzende yerleştirilmeyen tavus kuşları merkezdeki kantharosu kavramak üzere ayaklarını uzatırlar (Resim 12). Afyonkarahisar Müzesi’nde bulunan 6. yüzyıla tarihlenen sütun başlığında ${ }^{19}$ kantharosa tünemiş olan tavus kuşları simetrik bir düzende görülmez. Sağdaki tavus kuşu, kaba doğru eğilmişken soldaki diğerinin başına doğru uzanmış olarak tasvir edilmiştir (Resim 13).

\footnotetext{
${ }^{10}$ a.g.m. s.400.

${ }^{11}$ Alessandro Ruggieri, "Sculture di Ravenna fra V e VI secolo", ArcheoArte, Rivista elettronica di Archeologia e Arte, Supplemento 2012 al numero 1, Cagliari, s.586.

12 Birsen Bülbüloğlu, Bizans Sanatında Tavus kuşu Motifleri, (Yayınlanmamış Lisans Tezi), 1972, İstanbul Üniversitesi, İstanbul, s.12; Ayşegül Andıç, İzmir Arkeoloji Müzesi’ndeki Bizans Dönemi Taş Eserleri, Çanakkale Onsekiz Mart Üniversitesi Sosyal Bilimler Enstitüsü, Yayımlanmamış Yüksek Lisans Tezi, Çanakkale, 2012.

${ }^{13}$ Çiğgdem Temple, Konya/Ikonion ve Çevresinde Bulunan Bizans Dönemi Taş Eserleri, (Yayınlanmamış Doktora Tezi), Hacettepe Üniversitesi, Ankara, 2013, s.182.

${ }^{14}$ Ebru Parman, a.g.m. s.399.

15 a.g.e.

${ }^{16}$ Ayşe Çaylak Türker, Byzantine Architectural Sculpture in Çanakkale, Ankara, 2018, s.105, fig.189-190.

${ }^{17}$ Muhsine Eda Armağan, Kuşadası Kadıkalesi’ndeki Bizans Dönemi Taş Eserleri, (Yayınlanmamış Yüksek Lisans

Tezi), Ege Üniversitesi, İzmir, 2010, s.83.

18 a.g.e., s.144-145.

${ }^{19}$ Federico Guidobaldi; Claudia- Barsanti; Alessandra Guiglia Guidobaldi;. San Clemente La Scultura Del VI Secolo, Roma, 1992, s.150. Stube, Polyeuktoskirche und Hagia Sophia. Umbildung und Auflösung antiker. Formen, Entstehen des Kämpferkapitells, München 1984, s.57, fig.52-53.
} 
İkinci grubu oluşturan örneklerde merkezde bir çeşme ve onun her iki yanına yerleştirilmiş tavus kuşlarından oluşan bir düzenleme vardır. Bandırma Arkeoloji Müzesi'nde bulunan ve 7. yüzyıla tarihlenen kiborium kemerinde ${ }^{20}$ simetrik bir düzende görülen tavus kuşlarının ayakları zemine basmaktadır ve arka planlarının asma dallarıyla doldurulmuş olduğu görülür (Resim 14). İznik Müzesi'nde yer alan 8. yüzyıla ait korkuluk levhasında ${ }^{21}$ simetrik düzende yerleştirilmiş tavus kuşları ayaklarıyla merkezdeki çeşmeyi kavramaktadır (Resim 15). Aynı kompozisyon düzeni, Sofya Arkeoloji Müzesi’nde bulunan 11. yüzyıla ait levha ${ }^{22}$ üzerinde de görülür. Tavus kuşları ayaklarıyla merkezdeki çeşmeyi kavramaktadır. Sağdaki karşıya bakmakta iken soldaki tavus kuşu su içerken görülür (Resim 16).

Üçüncü grubu, merkeze yerleştirilmiş bir haç motifi ve iki yanına yerleştirilmiş tavus kuşları oluşturur. Bodrum Arkeoloji Müzesi'nde bulunan 11. yüzyıla ait levha ${ }^{23}$ üzerinde bir madalyon içerisinde yer alan sahnenin merkezinde bir Latin haçı bulunur. Haçın kollarından birer yaprak uzanır. Haçın alt kolları arasına yerleştirilmiş tavus kuşları simetrik değildir ve ayaklarıyla haçı kavrar şekilde gösterilmiştir (Resim 17). Ravenna St. Apollinare in Classe Bazilikası'nda bulunan lahit teknesinde ${ }^{24}$ iki sütun arasına yerleştirilmiş sahnenin merkezinde bir haç motifi yer alır. Haçın iki yanında farklı boyutlarda tavus kuşları görülmektedir. Tavus kuşları olasılıkla cennetin dört ırmağını simgeleyen bir zemine basmaktadır. Sağdaki tavus kuşu karşıya bakarken soldaki yukarıya doğru bakmaktadır. Haçın hemen altında üsluplaştırılmış bir bitki motifi bulunur (Resim 18).

Sıklıkla tavus kuşlarıyla gösterilen bu tür kompozisyonların inançlı insanı sembolize eden güvercin, geyik ya da kuş figürleri gibi cennete ait hayvan figürleriyle de kullanılmış olduğu görülür. $\mathrm{Bu}$ kompozisyonu iki grupta toplayabiliriz. Bunlardan birinci grubu, bir kabın iki yanına yerleştirilen kuş figürleri oluşturur. Bu kompozisyon düzenini görebildiğimiz İstanbul Arkeoloji Müzesi’nde bulunan sütun kaidesi ${ }^{25}$ örneğinde simetrik bir düzende görülmeyen kuşlar merkeze yerleştirilmiş bir kabın iki yanında tasvir edilmiştir. Tek ayaklarını kaba doğru uzatan kuşlardan sağdaki başını geriye doğru

\footnotetext{
20 “Kalanlar”:12. Ve 13. Yüzyıllarda Türkiye’de Bizans, (ed.Ayla Ödekan), İstanbul,2007; Ebru Parman, a.g.m. s.401, Başak Çoraklı, "Çini ve Seramiklerde Tavus kuşu Figürü”, Mimar Sinan Güzel Sanatlar Üniversitesi Sosyal Bilimler Enstitüsü Dergisi, S.6, İstanbul, 2012, s.13.

${ }^{21}$ Tarih Boyunca İznik (ed. Işıl Akbaygil, Halil İnalcık, Oktay Aslanapa), İstanbul, 2004, s.283.; Ancak "Kalanlar" 12. ve 13. Yüzyıllarda Türkiye'de Bizans (ed. Ayla Ödekan),İstanbul, 2007,s.240. yayınında 11-13. yüzyıllara tarihlenmektedir.

${ }^{22}$ Bulgaria in the Byzantine World: Exhibition at 22nd International Congress of Byzantine Studies, (work of cat. Snezhana Goryanova) Sofia, 24th August - 30th September 2011, s.45.; 105Andre Grabar, Sculptures Byzantines Du Moyen Age II, Paris, 1976, s.72.

${ }^{23}$ Hatice Özcan Özyurt. "Examples of Architectural Sculpture with Figurative and Floral Decaration of the Byzantine period at Muğla,Bodrum and Milas Archaeolagical Museum”, OLBA XIX,2011, s.401.

${ }^{24}$ Ebru Parman, 1993, a.g.m., s.398.

${ }^{25}$ Nezih Firatl1, La Sculpture byzantine figurée au Musée archéologique d'Istanbul, Paris, 1990, s.100; Gustave Mendel, Catalogue des Sculptures Grecques, Romaines et Byzantines, c.II, Constantinople, 1914, s.535, no:738 (1641).
} 
çevirirken soldaki kaba doğru yönelmiştir (Resim 19). Benzeri 6. yüzyıla ait Kuyumcu Symeonios'un mezar taşında ${ }^{26}$ görülür. Ancak burada kuşlar havada duruyor izlenimi verir (Resim 20).

Diğer grubu, merkezdeki bir kabın iki yanına yerleştirilmiş geyik figürleri oluşturur ${ }^{27}$. Bu gruba giren eser, Ravenna Quadrarco di Braccioforte, Eliseo Profeta'nın 5-6. yüzy1llara tarihlenen lahit teknesinde ${ }^{28}$ görülür (Resim 21). Geyikler, içi su dolu kantharosun iki yanına simetrik bir düzende yerleştirilmiş ve ayakları zemine basmaktadır.

Bizans taş eserlerinde tek başına tasvir edilen tavus kuşu ve geyik figürleri de liturjik işleve sahip eserler üzerinde sıklıkla görülmektedir. Geyik ve tavus kuşunun çeşitli sembolik anlamlarının yanı sıra tek başlarına tasvir edilmeleri, karşılıklı yerleştirilmiş bir düzende görülmelerinden dolayı refrigeriuma atıf yapıldığını gösterebilir. Bu tür örneklerden Koyunoğlu Müzesi’nde sergilenen ambon yan levhasındaki $^{29}$ figür, bir ayağı havada ve hareket halinde görülür. Başı sağa doğru dönük bir şekilde tasvir edilmiştir (Resim 22). Benzer kompozisyondaki örnekler, Ankara Anadolu Medeniyetleri Müzesi'nde bulunan levhada ${ }^{30}$, Afyon Müzesi'nde bulunan ambon yan levhalarında ${ }^{31}$, Milas Müzesi ambon yan levhasında ${ }^{32}$ ve San Salvatore Müzesi’nde bulunan ambon veya kiborium frizinde $^{33}$ görülür (Resim 23-26). Ancak burada farklı olarak arka plan asma yaprakları ve üzüm salkımları ile tamamen doldurulmuştur. Aynı kompozisyon düzenindeki Afyon Arkeoloji Müzesi’nde bulunan ambon yan levhasında ${ }^{34}$ tavus kuşu yerine geyik figürü, sağ tarafa dönmüş şekilde tasvir edilmiştir (Resim 27). Benzer örneği, Kütahya Müzesi’nde bulunan 5-6. yüzyıllara tarihlendirilen ambon yan levhasında görülür ${ }^{35}$. Sağ tarafa dönmüş şekilde ve hareket halinde tasvir edilen geyik

\footnotetext{
${ }^{26}$ Demetra Papanikola-Bakirtzi, Everyday Life in Byzantium, Athens, 2002, s.100.

${ }^{27} \mathrm{Bu}$ geyik figürlerinin yerine kuzu geçebilir. Bkz: Ravenna, Galla Placidia Mozolesi, III. Valentinianus Lahiti, lahit kapağın sağ ucu. (https://www.christianiconography.info/Edited\%20in\%202013/Italy/sarcValentine3.lidRightEnd.html Erișim Tarihi: 08.02.2020)

${ }^{28}$ Ruggieri, Alessandro,"Sculture di Ravenna fra V e VI secolo, ArcheoArte, Rivista elettronica di Archeologia e Arte, Supplemento 2012 al numero 1, Cagliari, 2012, s.589.

${ }^{29}$ Çiğdem Temple, Konya/Ikonion ve Çevresinde Bulunan Bizans Dönemi Taş Eserleri, Hacettepe Üniversitesi Sosyal Bilimler Enstitüsü, Yayınlanmamış Doktora Tezi, 2013, Ankara, s.181; Mükerrem Usman Anabolu, "Batı Anadolu'da Bulunmuş Olan Yayınlanmamış Tavus kuşu Motifli Mimarlık Elemanları”, Türk Arkeoloji Dergisi, Sayı: XXVII, 1988, Ankara, s.103.

30 a.g.m.,s.50.

${ }^{31}$ Ebru Parman, Ortaçağda Bizans Dönemi’nde Frigya (Phyrgia) ve Bölge Müzelerindeki Bizans Taş Eserleri, Eskişehir, 2002, s. 135 .

32 Tavus kuşu burada arka kısmına doğru uzanan asma dalına basmaktadır. Zeynep Mercangöz, "Milas Müzesi’ndeki Bizans Ambon Elemanları" Sanat Tarihi Dergisi, S.8,1996, s.84.

${ }^{33}$ Neil, Christei, From Constantine to Charlemagne An Archaelogy of Italy AD 300-800, Cornwall, 2008, s.47; Crown and Veil : Female Monasticism From the Fifth to the Fifteenth Centuries (ed. Jeffrey F. Hamburger-Susan Marti), New York 2008, s. 18.

${ }^{34}$ Ebru Parman, a.g.e., 2002, s.136.

${ }^{35}$ Philipp Niewöhner, "Phrygian marble and stonemasonry as markers of regional distinctiveness in Late Antiquity", in P. Thonemann (Ed.), Roman Phrygia: Culture and Society (Greek Culture in the Roman World, Cambridge: Cambridge University Press, 2013, s.242.
} 
figürünün ön ayaklarından biri havadadır. Hemen önünde yer alan asma dallarına uzanır şekilde tasvir edilmiştir (Resim 28).

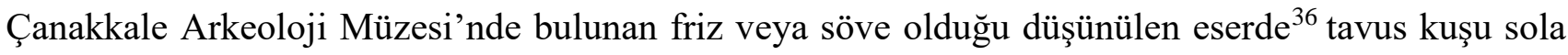
bakar şekilde tasvir edilmiştir (Resim 29). Yatay olarak uzanan dala parmak uçlarıyla dokunan tavus kuşunun hemen önünde küçük boyutlu bir kap görülür. İzmir Arkeoloji Müzesi’nde bulunan levhada ${ }^{37}$ tavus kuşunun gövdesi sola doğru dönükken başını sağa doğru çevirmiştir (Resim 30). Argos Müzesi'nde bulunan levhada ${ }^{38}$ figür sağa dönük bir şekilde üzüm gagalamakta ve bir ayağı havada kıvrılan asma dalına değmekte diğer ayağı ise dala basmaktadır (Resim 31). Golemo Gradište yapılan kazı sonucu bulunan ve daha sonra Üsküp Arkeoloji Müzesi’ne taşınan ambon yan levhasında ${ }^{39}$ ise ayakları zemine basan tavus kuşu sağa doğru bakarken tasvir edilmiştir. Arka planda stilize bitki motifi kıvrılarak tüm alanı kaplamaktadır (Resim 32).

\section{Refrigerium Kavramı ve İkonografisi}

Literatürde refrigerium olarak yer alan bu sahneler 4. yüzyıldan 13. yüzyıla kadar sıkça tekrarlanarak kullanılmışlardır. Refrigerium kelimesinin Türkçede tam bir karşılığ1 yoktur. Refrigerium, pagan ve erken Hıristiyan inancında ölen kişiyi anma amaçlı mezarlığın yakınında kutlanan ziyafet aynı

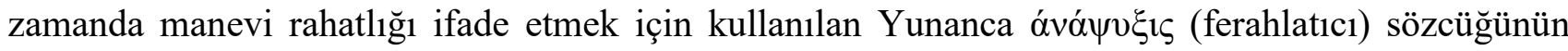
Latince karşılı̆̆ıdır ${ }^{40 .}$

Roma'da İskenderiye tanrılarının taraftarlarının mezar taşlarında Mısır ölüm kültüyle ilişkili olan “Osiris sana taze su versin” ifadesi tipik bir dua olur ve çok geçmeden bu su sembolik bir anlamda, susuzluk çeken ruhlara ölümsüzlük saçan bir yaşam pınarı haline gelir ${ }^{41}$. İlk uygulama nedeni ruhsal rahatlığın sağlanması için yeterli yiyecek ve içecek yoluyla ölüleri beslemek olan bu inanç, pagan inancında başkalaşıma uğrayarak ölümden sonra ruhun geçici olarak kaldığı yer veya ölen kişinin affı için düzenlenen cenaze yemekleri vasıtasıyla Tanrı'ya dua etmesine dönüşür ${ }^{42}$. Bu terimin nadiren

\footnotetext{
${ }^{36}$ Ayşe Çaylak Türker, "Byzantine Liturgical Stone Works in Çanakkale Archaeology Museum: Marble Slabs", ASMOSIA X, ITALYA, 21-26 May 2012, s.388-389; Mükerrem Usman Anabolu, "Batı Anadolu'da Bulunmuş Olan Yayınlanmamış Tavus kuşu Motifli Mimarlık Elemanları”, Türk Arkeoloji Dergisi, Sayı: XXVII, Ankara, 1988, s.103.

37 Ayşe Aydın, “Ankara Anadolu Medeniyetleri Müzesi’ndeki Bir Kiliseye Ait Mimari Parçalar”, Belleten, LXVI, 245, 2002, s.53.

38 Andre Grabar, Sculptures Byzantines Du Moyen Age II, 1976, Paris, s.110.

39 Snively, Carolyn S. "Golemo Gradište at Konjuh: An Unidentified Late Antique City and Its Churches." Acta XV Congressus Internationalis Archaeologiae Christianae 2008, 2013, s.403-414.

40 Terim için bkz: Gerardus van der Leeuw, "Refrigerium", Mnemosyne, C.3, S.3, Fasi.2, Brill Yayınevi, 1936, s.125.; André Parrot, "Le « Refrigerium » dans l'au=delà: Chapitre IV. — Rome, Afrique du Nord et Gaule", Revue de l'histoire des religions, Vol.115, Paris, 1937, s.56.

${ }^{41}$ Franz Cumont, The Oriental Religions in Roman Paganism, Chicago, 1911, s.102.

${ }^{42}$ Encountering the Sacred The Debate on Christian Pilgrimage in Late Antiquity (ed. Peter Brown), İngiltere, 2005 , s.136.
} 
mezar taşlarında da geçtiği görülür $(\operatorname{Resim} 33)^{43}$. Pagan geleneğinde, ölmüş kişilerin aile üyeleri ve arkadaşları onları ferahlatmak için düzenli aralıklarla mezarlarına gelirler. Ölen kişinin ruhuna teselli vermek için yemek ziyafeti verilir ${ }^{44}$. Böylece, üst ve alt dünyalar arasında sosyal bağlantı kurulur. Bu cenaze töreninde, ölmüş kişi kline üzerine uzanmış olarak gösterilirken, ölen kişinin adına içmek için elinde bardak tutan kişiler görülür. Bu tasvirler Yunan heykelleri ve Roma freskolarında sıklıkla kullanılmıştır ${ }^{45}$. Doğrudan bir köken çizgisi belirlenememesine rağmen bu terim, Yunan mitolojisinde Tantalos hikayesine benzetilebilir ${ }^{46}$.

Afrikalı ilk teologlardan olan Tertullian refrigerium'un yaratılan cennetle cehennem arasındaki başka bir seviyeyi tanımlayan bir yer olduğundan bahseder ${ }^{47}$. Tertullian'a göre ölüler dirilişi beklerken cennet ve cehennem arasında bulunan ve refrigerium denilen üçüncü bir yerde beklerler. Daha sonraki Hıristiyan yazarlar arasında, refrigerium, iyi ruhlara Tanrı tarafından vaad edilen mezarın ötesindeki dünyanın keyiflerini göstermek için genel bir şekilde kullanılır ${ }^{48}$. Christine Mohrmann ise bir çalışmasında, bu oldukça belirsiz ve değişen tanımların yanısıra refrigerium'un İbrahim'in kucağında Mesih'in dönüşünü bekleyen ruhların geçici mutluluğunu ifade ettiğinden bahseder ${ }^{49}$. Le Goff, refrigerium'un Tertullian'ın kişisel düşüncesi gibi geçici bir yer olmadığını, Mohrmann'ın bahsettiği gibi yarı cennete benzer bir mutluluk halini ifade ettiğinden söz eder ${ }^{50}$. Bu bağlamda refrigerium araf olarak düşünülebilir. Ancak Tertullian'a göre ikisinin arasında ince bir ayrım vardır. Ruhlar son yargıya kadar refrigerium'da huzurlu bir bekleyiştedir. Araf ise, cezalandırıcı ve kefaret ödeme türünden bir yer olduğu için günahlarının acısını çekmek amacıyla bir süre ruhların kaldıkları yerdir ${ }^{51}$. Tertullian'ın düşüncelerinin yanı sıra elimizdeki en eski belge ile refrigerium'un belirtisini yakalamak mümkün olacaktır. The Passion of Perpetua and Felicitas başlıklı M.S. 3. yüzyılın başından kalma bir metin, şehit olan birkaç Hıristiyanın öyküsünü anlatır. Hikayede, inancı için Romalılar tarafından

\footnotetext{
${ }^{43}$ Ayrıntılı bilgi için bkz: Ennabli Liliane. "Les inscriptions funéraires chrétiennes de Carthage", III. Carthage intra et extra muros Rome : École Française de Rome, 1991, s.3-397. James Spencer, Epitaphs of the Catacombs; or, Christian inscriptions in Rome during the first four centuries, İngiltere,1878; Orazio Marucchi, Christian Epigraphy; an Elementary Treatise, with a Collection of Ancient Christian Inscriptions Mainly of Roman Origin (çev. J. Armine Willis), Cambridge, 1912, s.141,150,163,325.

${ }^{44}$ Robin M. Jensen, Dining with the Dead: From the Mensa to the Altar in Christian Late Antiquity, Commemorating the Dead Texts and Artifacts in Context (ed. Laurie Brink, O.P, Deborah Green), New York, 2008, s.122.

${ }^{45}$ Ayrıntılı bilgi için bkz: Robin M. Jensen, Dining with the Dead: From the Mensa to the Altar in Christian Late Antiquity, Commemorating the Dead Texts and Artifacts in Context (ed. Laurie Brink, O.P, Deborah Green), New York, 2008, s.108116.

${ }^{46}$ Hikaye için bkz: Robert Graves (çev. Uğur Akpur), Yunan Mitleri Tanrılar, Kahramanlar, Söylenceler, İstanbul, 2010, s.527.

${ }^{47}$ Jacques Le Goff, The Birth of Purgatory (çev. Arthur Goldhammer), İngiltere, 1984, s.47.

48 a.g.e., s.46.

${ }^{49}$ Christine Mohrmann, "Locus refrigerii, lucis et pacis" Questions liturgiques et paroissiales, 39, Paris, 1958, s.196-214.

${ }^{50}$ Jacques Le Goff, a.g.e., s.46.

51 a.g.e., s.47-48.
} 
tutuklanan Perpetua, rüyasında ölülerin acı çektiği bir yerde onbir yaşında hastalıktan ölen erkek kardeşi Dinocratus'u görür. Genç çocuk pis, paçavralar içinde yanmakta ve susuzluktan kavrulmaktadır. Perpetua, kardeşinin küçük bedeni için çok yüksek olan bir havuza uzanmaya çalıştığını görür. İnançlı olan Perpetua şehit olmak üzere olduğundan kardeşine müdahale edebileceğini düşünür ve gece gündüz ağlayarak kardeşi için dualar eder. Birkaç gün sonra ikinci rüyasında, kardeşinin temiz giyimli ve en önemlisi uzanmaya çalıştığg havuzun alçalmış olduğunu görür. Kardeşi, havuz kenarında duran su dolu altın kaptan su içmekte ve su hiçbir şekilde azalmamaktadır. Eskiden olduğu gibi kardeşinin mutlu bir şekilde su ile oynadığını gören Perpetua onun ferahlamış (refrigerantem) olduğunu düşünür ve cezasının kalktığını anlar ${ }^{52}$. Burada önemli olan kelime açıkça refrigerium kavramı ile ilgili olan refrigarentem'dir. St. Augustine döneminden itibaren, bu metin araf olduğu düşüncesi barındıran eserlerde kullanılmıştır ${ }^{53}$. Susuzluk çekmeleri diğer dünyada cezalandırılanların tipik bir 1stırabı olarak görülmüş ve bağışlanması için dua edilerek susuzluğun giderilebilecek olduğunu göstermiştir. Ayrıca Eski Ahit’te Mezmurlar 66:1254 ve Yeremya 6:16' da ${ }^{55}$ Yeni Ahit'te Tim2.1:16 ${ }^{56}$ ve Luka $16: 24^{\prime} \mathrm{da}^{57}$ bu kavramdan söz edildiği düşünülebilir.

Ölüm kültüyle ilişkili olan refrigerium, pagan katakomp freskolarında cenaze yemeği olarak sahnelenirken, Bizans sanatında sıklıkla kantharosun iki yanına yerleştirilmiş tavus kuşları olarak karşımıza çıkar (Resim 34-35). Bunun yanı sıra yukarıda bahsettiğimiz motifler kantharosun yerine kullanıldığı gibi kuş, güvercin ve geyik figürleri de tavus kuşları yerine kullanılabilir. Erken Hıristiyan sanatında kuşlar "kanatlı ruhun” sembolü olarak kullanılmıştır ${ }^{58}$. Güvercin figürü ise, saflığın ve barışın sembolü olarak karşımıza çıkmaktadır ${ }^{59}$.

Protohistorik dönemde Çin'den Batı Avrupa'ya kadar uzanan bir alanda, geyik boynuzlarının dönemsel yenilenmesi yüzünden, sürekli yaratılış ve renovatio (yenilenme) simgelerinden biri olduğu

\footnotetext{
${ }^{52}$ Hikaye için bkz: a.g.e, s.49.

53 a.g.e, s.50.

54 "İnsanı başımıza bindirdin; ateşe ve suya girdi; fakat bizi bolluğa çıkardın."

55 "Yollar üzerinde durun ve bakın, eski yolları sorun, iyi yol nerededir, öğrenin; ve onda yürüyün ve canlarınıza rahat bulursunuz, fakat o yolda yürümeyiz dediler."

56 "Onisiforos'un evine merhamet ihsan etsin; çünkü çok defalar beni ferahlandırdı, ve benim zincirimden utanmadı."

57 “Ey babamı İbrahim, acı bana! Lazar'ı gönder de parmağının ucunu suya batırıp dilimi serinletsin. Bu alevlerin içinde azap çekiyorum."

${ }^{58}$ George Ferguson, Signs \& Symbols in Christian Art, New York,1961, s.12.

59 a.g.e., s.15. Aynı zamanda bazı araştırmacılar bir kaptan su içen güvercinleri refrigerium sahnesi olarak tanımlamıştır; Bkz: Ertuğrul Özkan, “Bizans’ın Kültür Hayatı Üzerine” Sanat Tarihi Araştırmaları Dergisi, C.3, S.8, İstanbul, 1990,s.2838; Graydon F. Snyder, Ante Pacem: Archaeological Evidence of Church Life Before Constantine, s.39-41.
} 
görülür ${ }^{60}$. Yeni Ahit Mezmurlarda geçen "Rab, beni yemyeşil çayırlarda yatırır, sakin suların kıyısına götürür. İçimi tazeler."61 ayetinden yola çıkarak geyik figürü Hıristiyanlık inancında her ne kadar vaftiz ile ilişkilendirilse de "İçimi tazeler" ifadesi ile refrigeriuma da atıf yapabileceğini düşünebiliriz. Yenilenme temasıyla yakından bağlantılı olan kantharosun tasviri refrigerium sahnelerinin en önemli figürüdür. Aynı zamanda kantharosların ağız kısımlarından filizlenen asma dalları, üzüm salkımları ve akantus yaprakları sıklıkla refrigerium konulu taş eserlerde kullanılmıştır. Görüldüğü üzere cennnette sonsuz yaşamın ve yenilenen bir hayatın simgesi olan kantharoslar refrigerium ile yakından ilişkilidir. Bu kantharosların saf kutsal yaşam suyu fikrini yansıttığını düşünmekteyiz. Kantharosun içerisindeki suyun dalgalar şeklinde verilmesi erken Bizans örneklerinde görülür ${ }^{62}$.

\section{SONUÇ}

Sonuç olarak, ölüm kültüyle ilişkili olan refrigerium, Roma katakomb freskolarında cenaze yemeği olarak sahnelenirken Bizans sanatında değişime uğrayarak, sıklıkla kantharosun iki yanına yerleştirilmiş tavus kuşları olarak görülür. Cennette sonsuz yaşamın ve yenilenen bir hayatın simgesi olan kantharosların refrigerium ile yakından ilişkili olmasının yanı sıra bu sahnelerin hayat ağacı, çeşme, haç ve christogram ile de kullanıldığı görülür. Ayrıca sıklıkla tavus kuşlarıyla gösterilen bu sahnelerde, tavus kuşlarının yerine kuş, güvercin ve geyik figürleri gibi saflığın sembolü olan ve cennetle ilişkili hayvanlara da yer verildiği görülür.

Ele aldığımız taş eserlerin tümünde tavus kuşları profilden gösterilmiştir. Ancak cepheden gösterilen örnekler de bulunmaktadır ${ }^{63}$.

Arka planlarında stilize kıvrık dallar, akantus yaprakları, asma yaprakları ve üzüm salkımları görülür. Ancak üslup ve kompozisyon düzeni açısından incelendiklerinde herhangi dönemsel farklılığa rastlanmamıştır. Aynı sembolik işlev nedeniyle genellikle tek bir kompozisyon içinde birleştirildikleri düşünülebilir ${ }^{64}$.

\footnotetext{
60 Mircea Eliade, Dinsel İnançlar ve Düşünceler Tarihi , Gotama Budha'dan Hıristiyanlığın Doğuşuna, C.2, İstanbul, 2003, s.169.

${ }^{61}$ Mezmur 23:3.

${ }^{62}$ İncelenen eserler arasından Ravenna Sant'Apollinare in Classe Bazilikası'nda bulunan lahit teknesinde ve Berlin Bode Müzesi'nde bulunan korkuluk levhasında tespit edilmiştir.

${ }_{63}$ İstanbul Arkeoloji Müzesi’nde bulunan 2655 envanter numaralı 6. yüzyıla tarihlenen Ion-impost sütun başlığı. Bkz: Nezih Firatl1, La Sculpture Byzantine Figuree au Musee Archeologique D’Istanbul, Paris, 1990, s.116; İstanbul, Studios Manastırı kazılarında bulunan ve 1910 yılında İstanbul Arkeoloji Müzesi’ne taşınan 6. yüzyıla tarihlenen korkuluk levhasının parçası. (Bkz: Gustave Mendel, Catalogue des Sculptures Grecques, Romaines et Byzantines, c.II, Constantinople, 1914, s.518, no:721 (2434).

${ }^{64}$ Sembolik anlamları için Bkz: George Ferguson, Signs \& Symbols in Christian Art, New York,1961.
} 
Tek başına görülen tavus kuşu ve geyik figürleri genellikle dik üçgen veya dik yamuk içerisine yerleştirilmiştir. 6. yüzyıldan sonra İzmir Arkeoloji Müzesi’nde bulunan levhada olduğu gibi profillerin inceldiği görülür.

Erken Hıristiyan Sanatı süsleme programında yer alan üzüm gagalayan tavus kuşu motifli eserler genel olarak 5.-6.yüzyıllara tarihlenmiştir ${ }^{65}$. Ravenna St. Apollinare Classe Bazilikası'nda bulunan lahit kapağındaki sahne bu tespiti doğrular niteliktedir. Ancak, Argos Müzesi'nde bulunan levha A. Grabar tarafından 12. yüzyıla tarihlenerek bu tespite uymamaktadır ${ }^{66}$.

Bizans sanatında, 4. yüzyıldan 13. yüzyıla kadar sıklıkla kullanılan refrigerium sahneleri, mezar odalarında, minyatür ve el yazmalarında görülürken taş eserler grubu içerisinde daha çok litürjik işleve sahip eserlerde kullanılır. Ayrıca daha çok, karşılıklı yerleştirilen ambon levhalarında tespit edilen, tek başlarına tasvir edilmiş tavus kuşu ve geyik figürlerinin de olasılıkla refrigeriuma atıf yaptığı düşünülebilir.

65 O. Feld, Christliche Denkmäler aus Milet und seiner Umgebung, İstMitt 25,Deutsches Archäologisches Institut, Abteilung Istanbul, 1975, s.202'den aktaran Ayşe Aydın, a.g.m., s.56.

${ }^{66}$ Andre Grabar, a.g.e., s. 110. 


\section{KAYNAKÇA}

Altunay, E. (2015). Paganizm: Mezopotamya- Misır, C.2, İstanbul.

Andiç, A. (2012). İzmir Arkeoloji Müzesi'ndeki Bizans Dönemi Taş Eserleri, Çanakkale Onsekiz Mart Üniversitesi Sosyal Bilimler Enstitüsü, Yayımlanmamış Yüksek Lisans Tezi, Çanakkale.

Armağan, M. E. (2010). Kuşadası Kadıkalesi’ndeki Bizans Dönemi Taş Eserleri, Ege Üniversitesi Sosyal Bilimler Enstitüsü, Yayınlanmamış Yüksek Lisans Tezi, İzmir.

Arslan, A. (2014). Konya Çevresi Bizans Dönemi Mimari Plastiği, Anadolu Üniversitesi Sosyal Bilimler Enstitüsü, Yayınlanmamış Doktora Tezi, Eskişehir.

Aydın, A. (2002). “Ankara Anadolu Medeniyetleri Müzesi’ndeki Bir Kiliseye Ait Mimari Parçalar", Belleten, LXVI, 245, 50-66.

Bulgaria in the Byzantine World (2011). Exhibition at 22nd International Congress of Byzantine Studies, (katalog çalışması: Snezhana Goryanova) Sofia, 24th Ağustos30th Eylül 2011.

Bülbüloglu, B. (1972). Bizans Sanatında Tavus kuşu Motifleri, İstanbul Üniversitesi Edebiyat Fakültesi Yayınlanmamış Lisans Tezi, İstanbul.

Christei, N. (2008). From Constantine to Charlemagne An Archaelogy of Italy AD 300800 , Cornwall.

Cumont, F. (1911). The Oriental Religions in Roman Paganism,Chicago.

Crown and Veil (2008).: Female Monasticism From the Fifth to the Fifteenth Centuries (ed. Jeffrey F. Hamburger- Susan Marti), New York.

Çoraklı, B. (2012). "Çini ve Seramiklerde Tavus kuşu Figürü” Mimar Sinan Güzel Sanatlar Üniversitesi Sosyal Bilimler Enstitüsü Dergisi, Sayı:6, İstanbul, 7-16.

Encountering the Sacred The Debate on Christian Pilgrimage in Late Antiquity (2005). (ed. Peter Brown), İngiltere.

Feld, O. (1975) Christliche Denkmäler aus Milet und seiner Umgebung, İstMitt 25, Deutsches Archäologisches Institut, Abteilung Istanbul.

Ferguson, G. (1961). Signs \& Symbols in Christian Art, New York.

Firatl1, N. (1990). La Sculpture byzantine figurée au Musée archéologique d'Istanbul, Paris.

Goff, J. L. (1984). The Birth of Purgatory (çev. Arthur Goldhammer), ABD. 
Gonzales, E. (2014). The Fate of the Dead in Early Third Century North African Christianity: The Passion of Perpetua and Felicitas and Tertullian (Studien und Texte zu Antike und Christentum 83), Tübingen: Mohr Siebeck.

Grabar, A. (1963). Sculptures Byzantines de Constantinople IVe-Xe, Paris.

Grabar, A. (1976). Sculptures Byzantines Du Moyen Age II, Paris.

Graves, R. (2010). Yunan Mitleri Tanrılar, Kahramanlar, Söylenceler, (çev. Uğur Akpur), İstanbul.

Guidobaldi, F. B.; Guidobaldi, C.; Guiglia, A. (1992). San Clemente La Scultura Del VI Secolo, Roma.

Hippolyte, D. (1926). “Refrigirare, Refrigerium”, Journal des savants, Kasim 1926. s. 385390.

Jensen, R. M. (2008). Dining with the Dead: From the Mensa to the Altar in Christian Late Antiquity, Commemorating the Dead Texts and Artifacts in Context (ed. Laurie Brink, O.P, Deborah Green), New York.

“Kalanlar” (2007). 12. ve 13. Yüzyıllarda Türkiye'de Bizans (ed. Ayla Ödekan), İstanbul.

Karademir, T. (2019) Bizans Resim Sanatında Refrigerium Sahneleri, Çanakkale Onsekiz Mart Üniversitesi Sosyal Bilimler Enstitüsü Yayınlanmamış Yüksek Lisans Tezi, Çanakkale.

Laurie, B.; O.P; Green, D. (2008). Commemorating the Dead: Texts and Artifacts in Context, Berlin.

Leeuw, G. van der (1936). "Refrigerium”,Mnemosyne, Third Series, Vol.3,Fasc.2, 125148.

Liliane, E. (1991). "Les inscriptions funéraires chrétiennes de Carthage". III. Carthage intra et extra muros Rome : École Française de Rome, 3-397.

Marucchi, O. (1912) Christian Epigraphy; an Elementary Treatise, with a Collection of Ancient Christian Inscriptions Mainly of Roman Origin (çev. J. Armine Willis), Cambridge.

Mendel, G. (1914). Catalogue des Sculptures Grecques, Romaines et Byzantines, c.II.

Mercangöz, Z. (1996). "Milas Müzesi’ndeki Bizans Ambon Elemanları" Sanat Tarihi Dergisi, S.8, 81-98.

Milburn, R. (1988). Early Christian Art and Architecture, İngiltere.

Mohrmann, C. (1958). "Locus refrigerii, lucis et pacis" Questions liturgiques et paroissiales, 39, Paris, 196-214. 
Niewöhner, P. (2013). Phrygian marble and stonemasonry as markers of regional distinctiveness in Late Antiquity. In P. Thonemann (Ed.), Roman Phrygia: Culture and Society, Cambridge: Cambridge University Press, s.215-248.

Özkan, E. (1990). “Bizans'ın Kültür Hayatı Üzerine” Sanat Tarihi Araştırmaları Dergisi, C.3, S.8, İstanbul, 28-38.

Özyurt, H. Ö. (2011). "Examples of Architectural Sculpture with figurative and floral Decaration of the Byzantine period at Muğla, Bodrum and Milas Archaeolagical Museum", OLBA XIX, 390-418.

Papanikola- Bakirtzi, Demetra; (2002). Everyday Life in Byzantium, Athens.

Parman, E. (1993). "Bizans Sanatında Tavus kuşu İkonografisi" Sanat Tarihinde İkonografik Araştırmalar, Güner İnal'a Armağan,Ankara, 387-412.

Parman, E. (2002). Ortaçağda Bizan Dönemi’nde Frigya (Phyrgia) ve Bölge Müzelerindeki Bizans Taş Eserleri, Eskişehir.

Parrot, A. (1937). Le "Refrigerium" dans l'au- delâ, Paris.

Ruggieri, A. (2012) "Sculture di Ravenna fra V e VI secolo", ArcheoArte, Rivista elettronica di Archeologia e Arte, Supplemento 2012 al numero 1, Cagliari, 577590 .

Snively, C. S. (2013) "Golemo Gradište at Konjuh: An Unidentified Late Antique City and Its Churches." Acta XV Congressus Internationalis Archaeologiae Christiana 2008, ss. 403-414.

Spencer, J. (1878). Epitaphs of the Catacombs; or, Christian inscriptions in Rome during the first four centuries. İngiltere.

Tarih Boyunca İznik (2004). (ed. Işıl Akbaygil, Halil İnacık, Oktay Aslanapa), İstanbul.

Temple, Ç. (2013). Konya/Ikonion ve Çevresinde Bulunan Bizans Dönemi Taş Eserleri, Hacettepe Üniversitesi Sosyal Bilimler Enstitüsü, Yayınlanmamış Doktora Tezi, Ankara.

Türker Çaylak, A. (2009). "Byzantine Architectural Sculpture from Akköy on the Middle Scamander Valley in Hellespontus" Hacettepe Üniversitesi Edebiyat Fakültesi Dergisi, C.26, S.1, Ankara, 206-207.

Türker Çaylak, A. (2012). "Byzantine Liturgical Stone Works In Çanakkale Archaeology Museum: Marble Slabs", ASMOSIA X, ITALYA, 21-26 May 2012, 385-392.

Türker Çaylak, A. (2018). Byzantine Architectural Sculpture in Çanakkale, Ankara. 
Usman Anabolu, M. (1988). "Batı Anadolu'da Bulunmuş Olan Yayınlanmamış Tavus kuşu Motifli Mimarlık Elemanları”, Türk Arkeoloji Dergisi, Sayı: XXVII, Ankara, 101-112. 
Resim 1: Ravenna St. Appolinare Nuovo Bazilikası, Altar levhas1 ${ }^{67}$

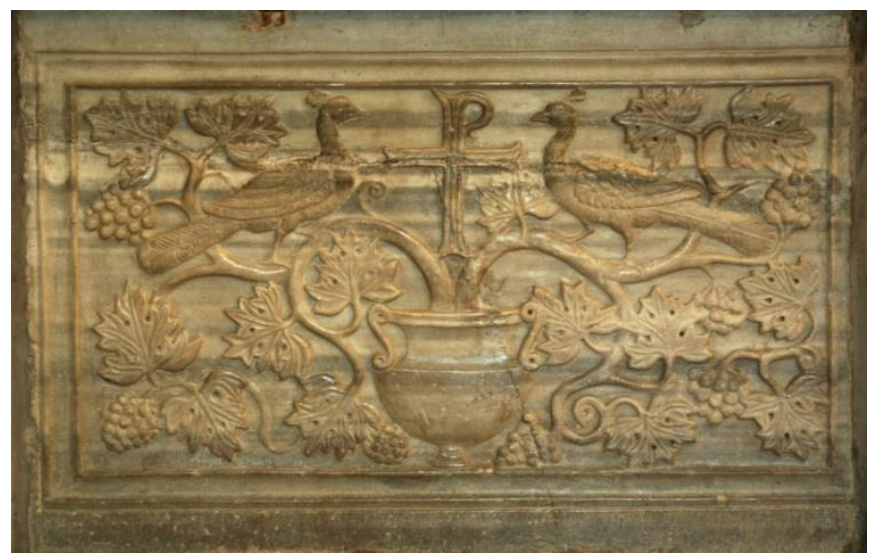

Resim 2: Berlin Bode Müzesi, Korkuluk Levhass ${ }^{68}$

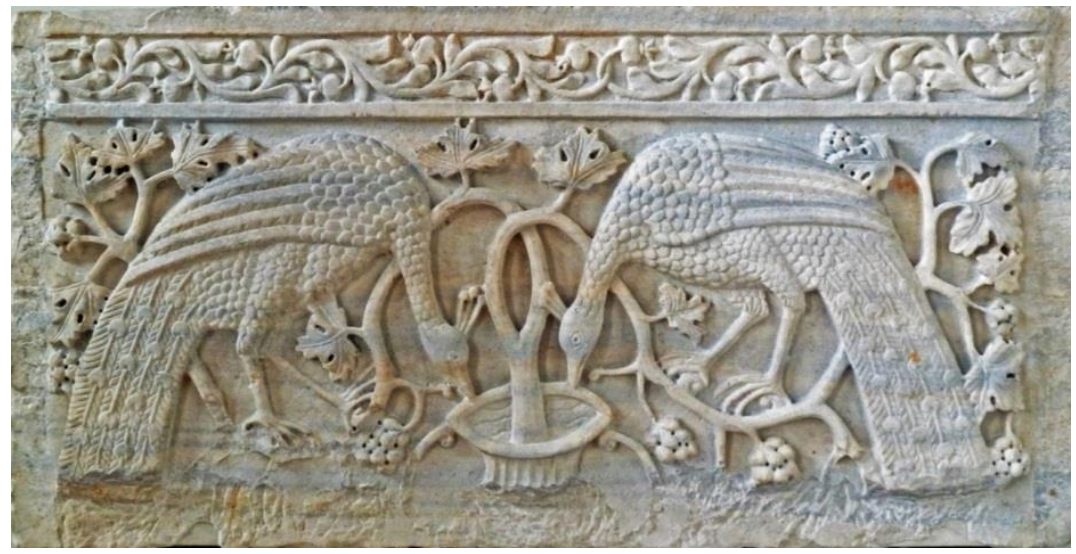

Resim 3: St. Maria Assunta Kilisesi, Levha ${ }^{69}$

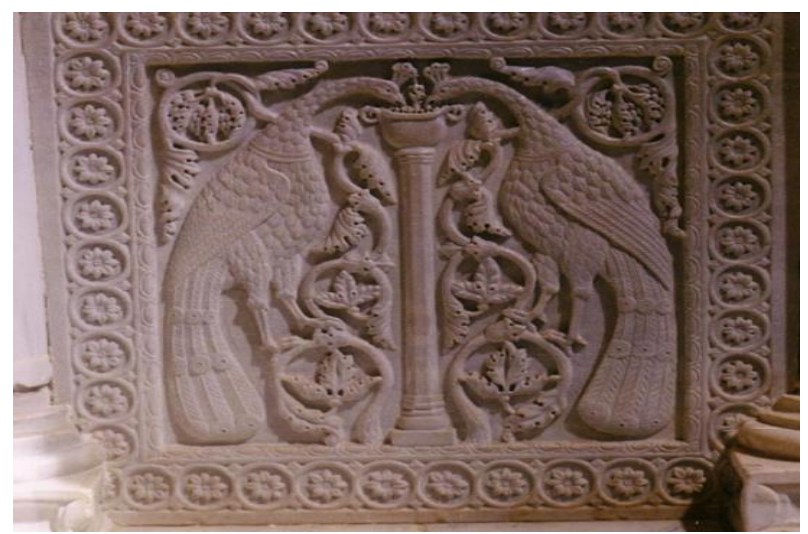

${ }^{67}$ https://www.flickr.com/photos/darkframe/316538638/in/gallery-adfinem-72157631422968702 Erişim Tarihi: $(04.01 .2020)$

${ }^{68}$ https://www.flickr.com/photos/28433765@N07/6264024392/in/photostream/ Erişim Tarihi: (04.01.2020)

${ }^{69} \mathrm{http}: / / \mathrm{www}$. lancaster.ac.uk/users/ruskinlib/eSoV/images/photos/veniceIB/142.jpg Erişim Tarihi: (04.01.2020) 
Resim 4: Ravenna St. Appolinare Nuovo Bazilikası, Lahit (Ruggieri, 2012)

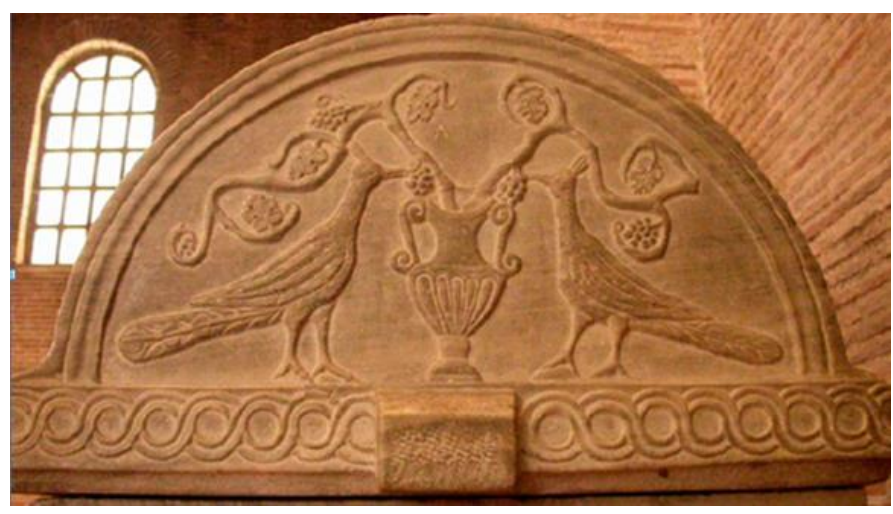

Resim 5: İzmir Arkeoloji Müzesi, Levha ${ }^{70}$

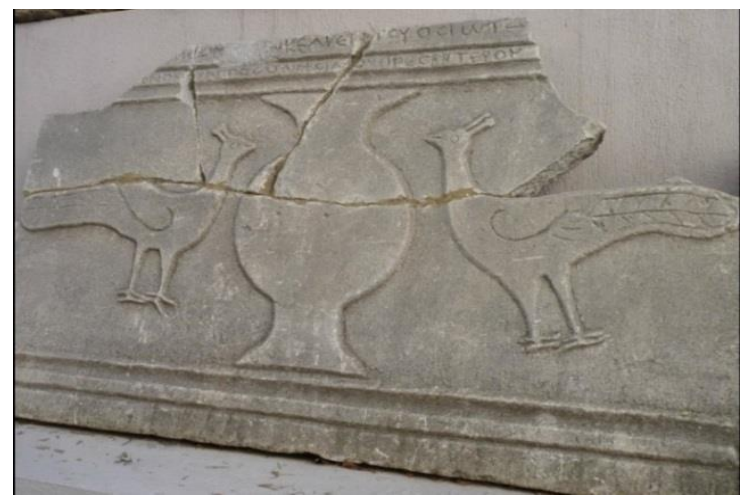

Resim 6: Konya Arkeoloji Müzesi, Kemer (Foto: Emel Karademir Balkır)

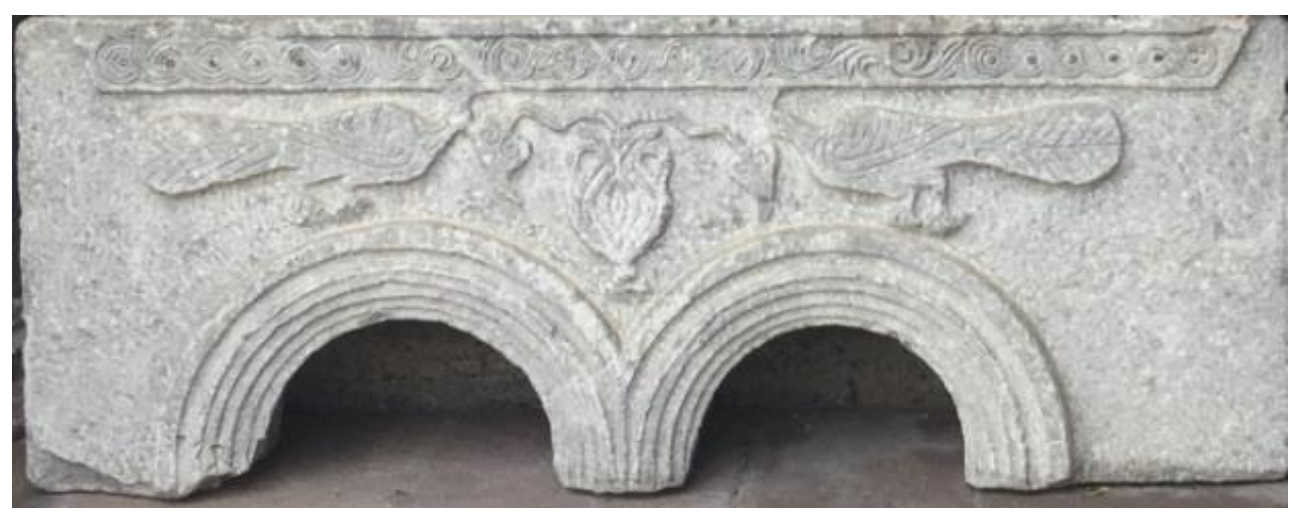

70 https://www.tripadvisor.com.tr/Attraction_Review-g298006-d302534-Reviews-Archaeological_Museum_of_IzmirIzmir_Izmir_Province_Turkish_Aegean_Coast.html\#photos; aggregationId=101\&albumid=101\&filter=7\&ff=98457525 Erişim Tarihi: (04.01.2020) 
Resim 7: Sakarya Arkeoloji Müze bahçesi, Levha ${ }^{1}$

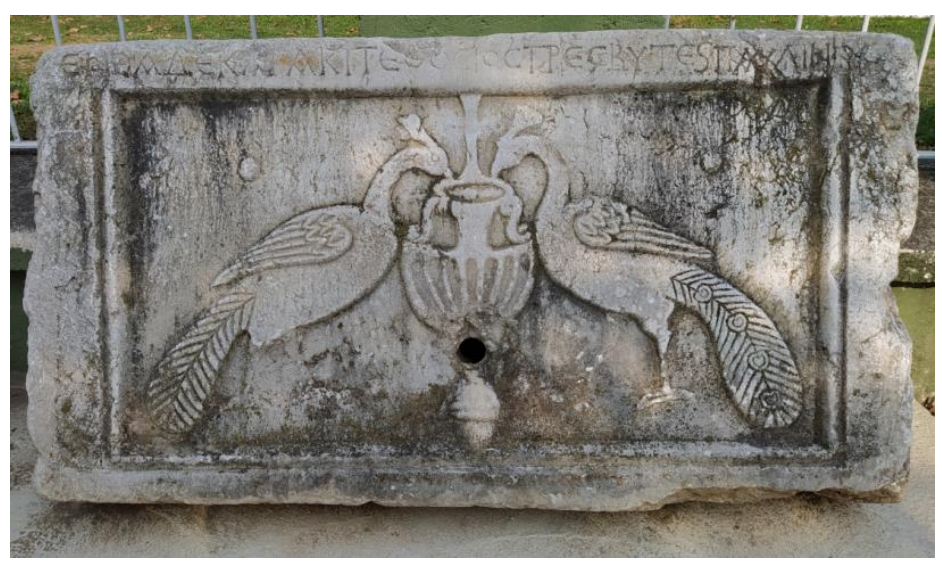

Resim 8: İtalya Pavia Müzesi, Lahit (Gannon, 2010)

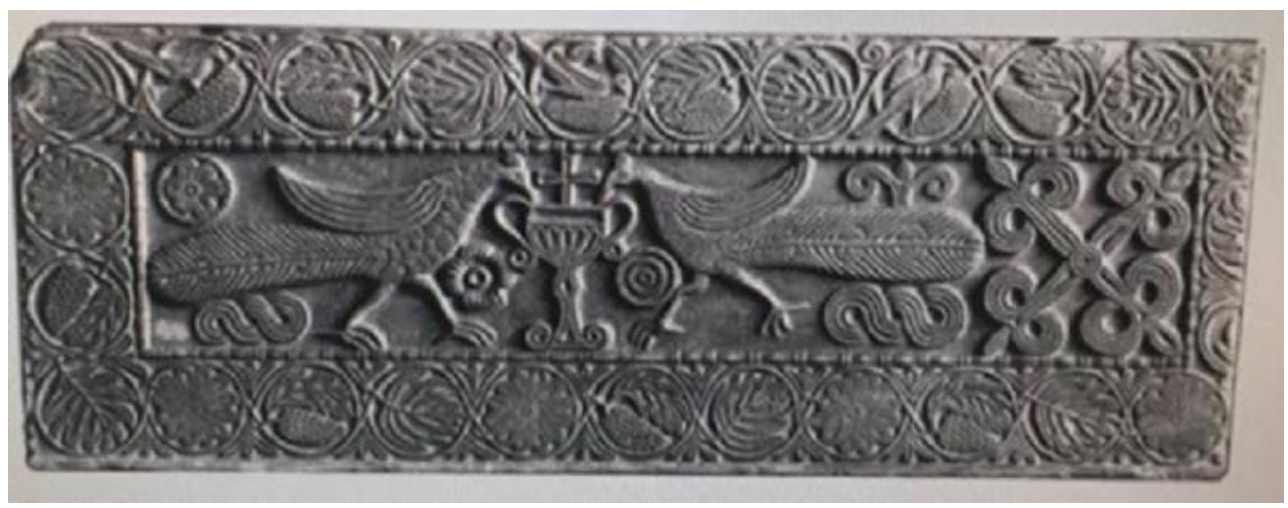

Resim 9: Konya Ilgın, Beykonak Köyü, Levha (Arslan, 2014)

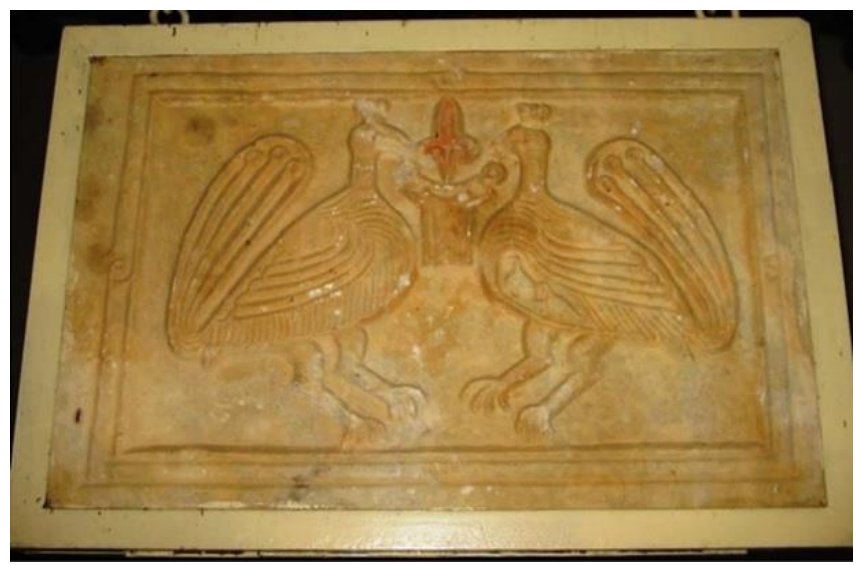


Resim 10: Çanakkale, Ayvacık, Tuzla Murat Hüdavendigar Cami, Arşitrav (Türker, 2018)

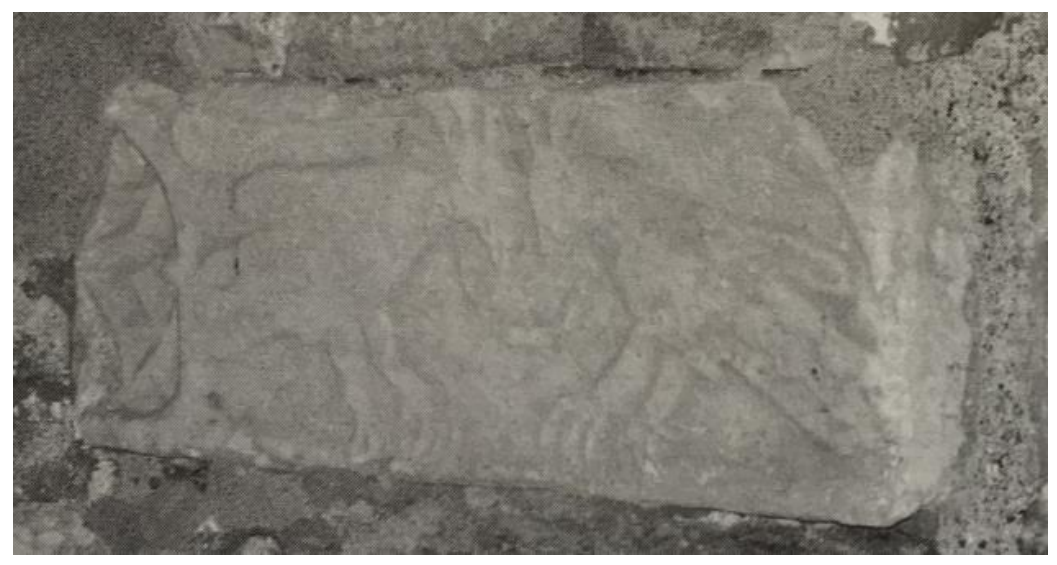

Resim 11: Kuşadası Kadıkalesi, Levha (Armağan, 2010)

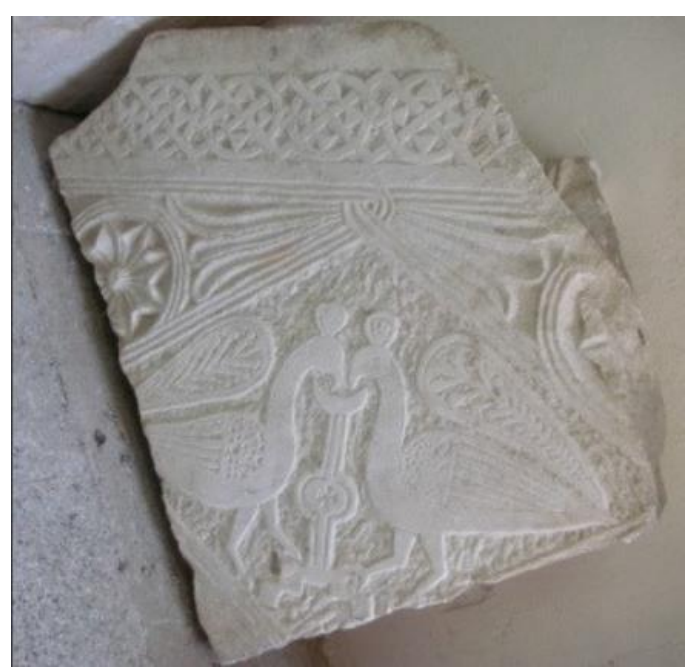

Resim 12: Konya Arkeoloji Müzesi, Levha (Temple, 2013)

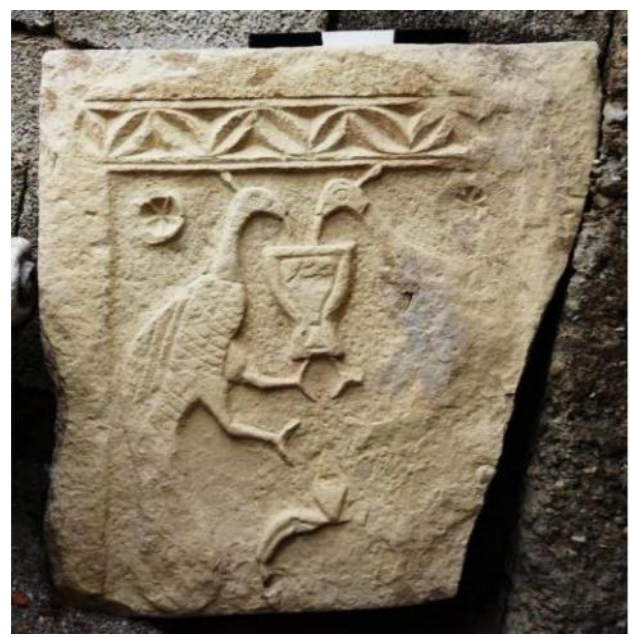


Resim 13: Afyonkarahisar Müzesi, Sütun Başlığı (Guidobaldi; Barsanti,1992)

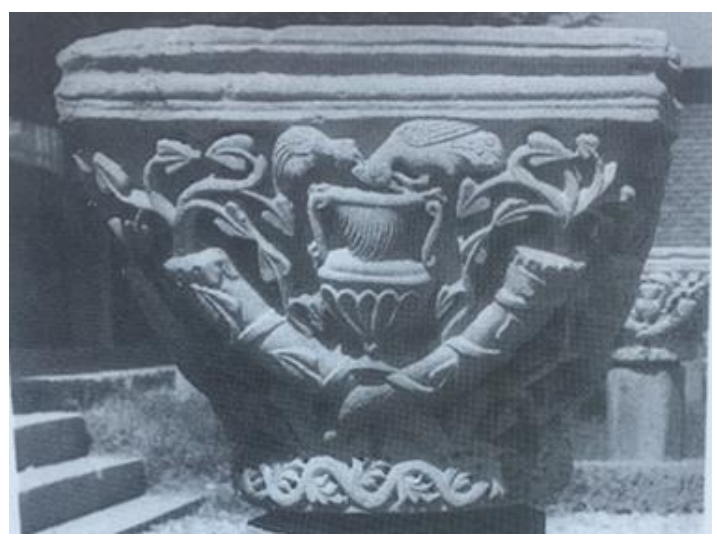

Resim 14: Bandırma Arkeoloji Müzesi, Kiborium Kemeri

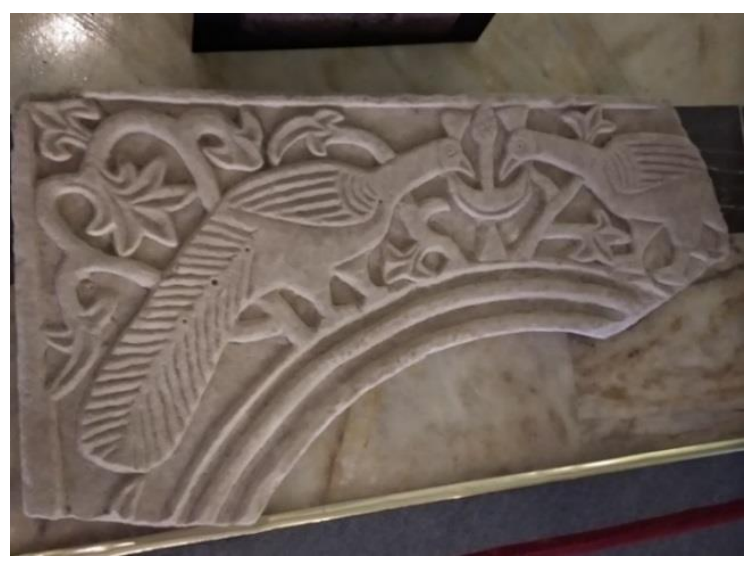

Resim 15: İznik, Korkuluk Levhası (Tarih Boyunca İznik, 2004) ${ }^{71}$

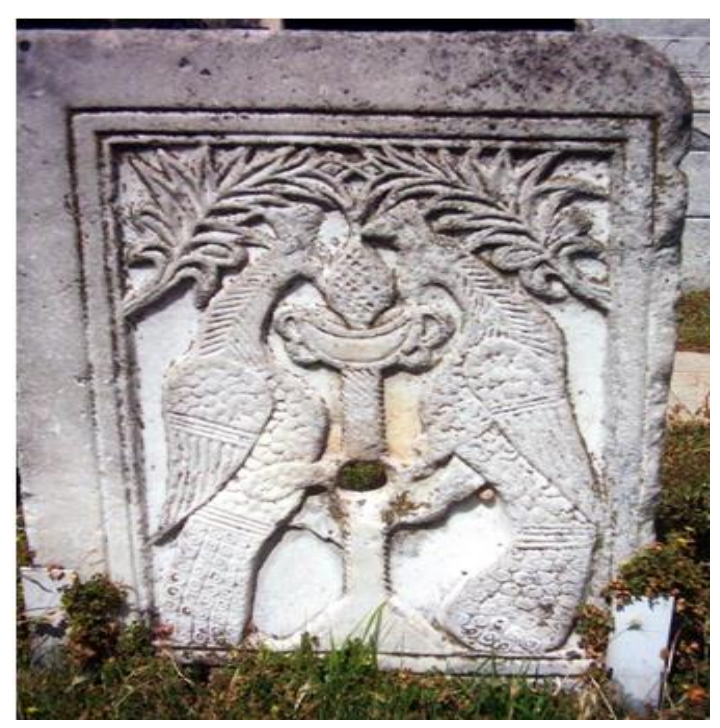

\footnotetext{
${ }^{71}$ https://goo.gl/maps/TmBKERTFi5Vn4epx7 Erişim Tarhi: (04.01.2020)
} 
Resim 16: Sofya Arkeoloji Müzesi, Levha (Snezhana Goryanova,2011)

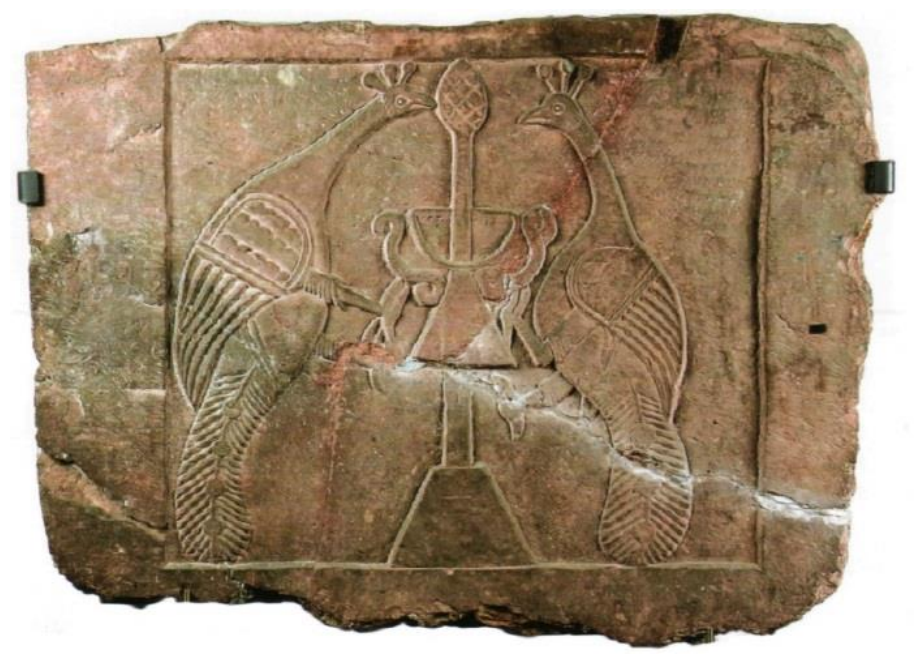

Resim 17: Bodrum Arkeoloji Müzesi, Levha (Özyurt,2011)

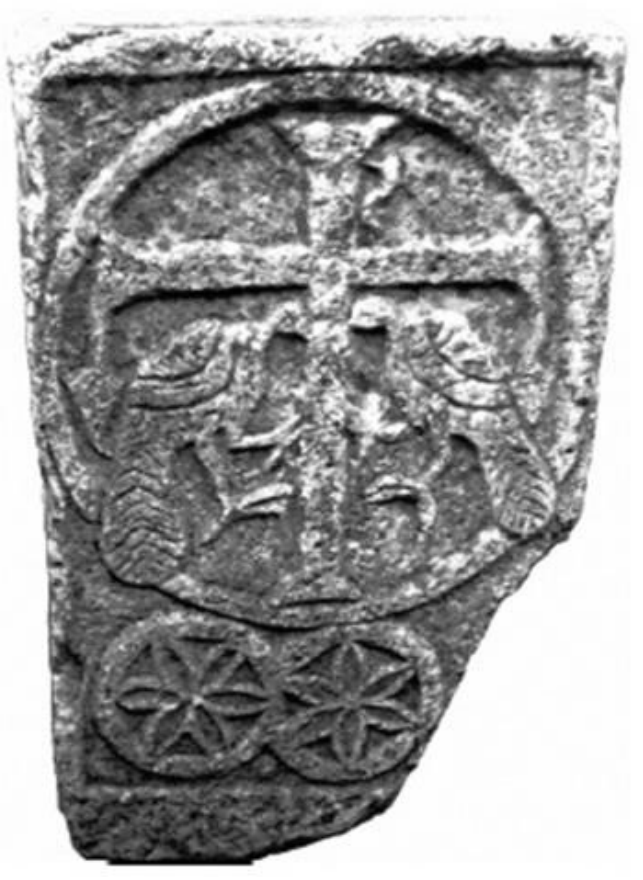


Resim 18: Ravenna St. Apollinare in Classe Bazilikas1, Lahit teknesi ${ }^{72}$

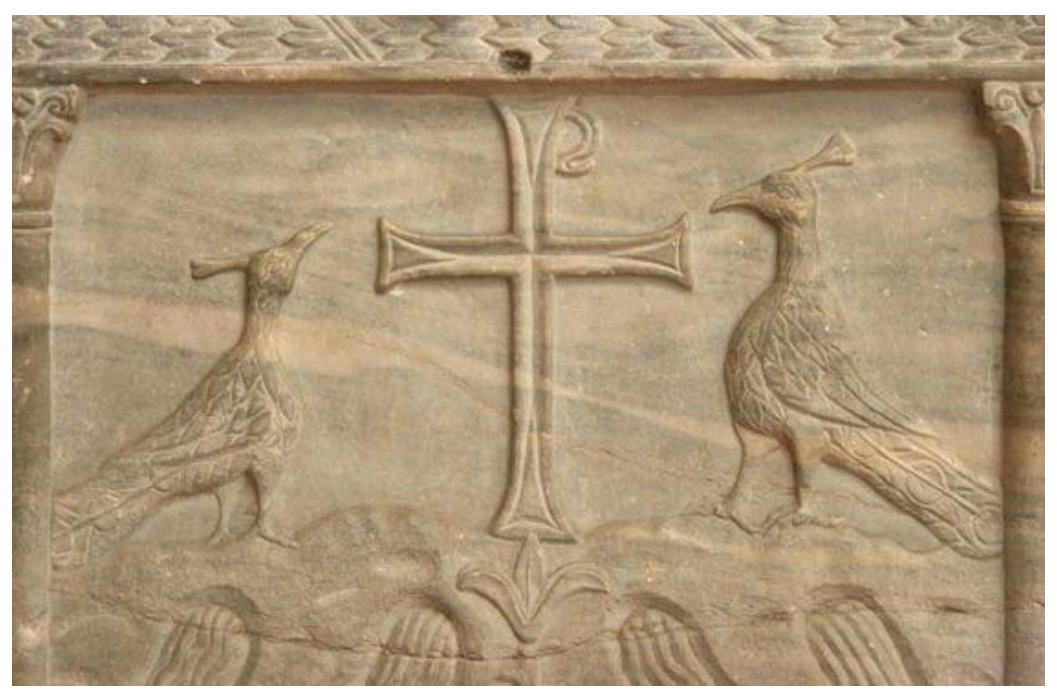

Resim 19: İstanbul Arkeoloji Müzesi, Kolon (Firatlı,1990)

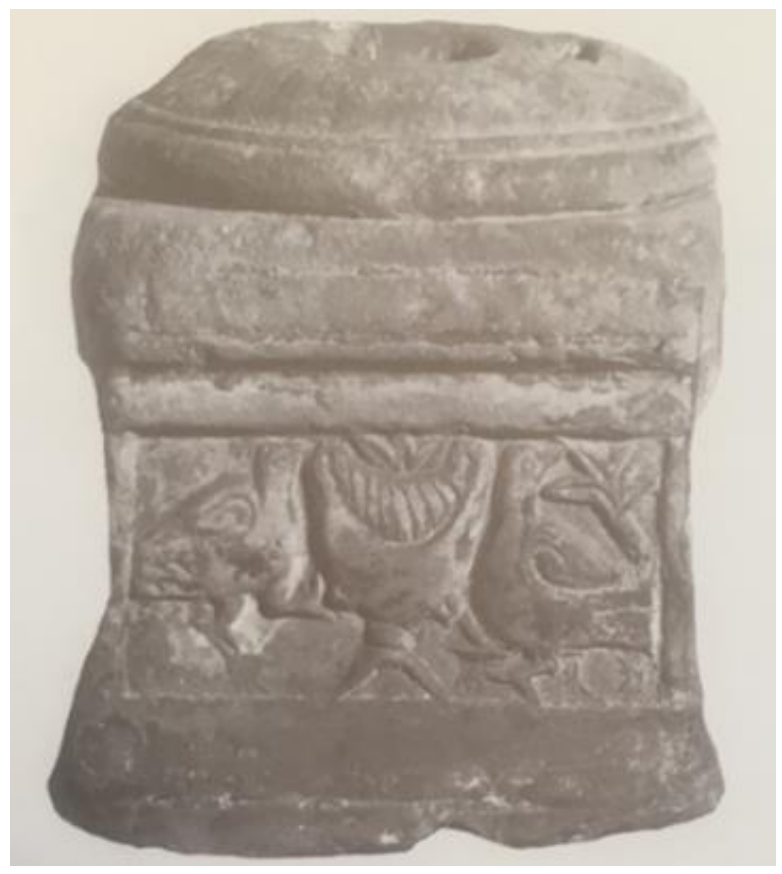

${ }^{72}$ https://i.pinimg.com/originals/93/82/83/938283e21d2485626e897b6888bbd01e.jpg Erişim Tarihi: (20.09.2017) 
Resim 20: Kuyumcu Symeonios'un Mezar Taşı (Bakirtzi, 2002)

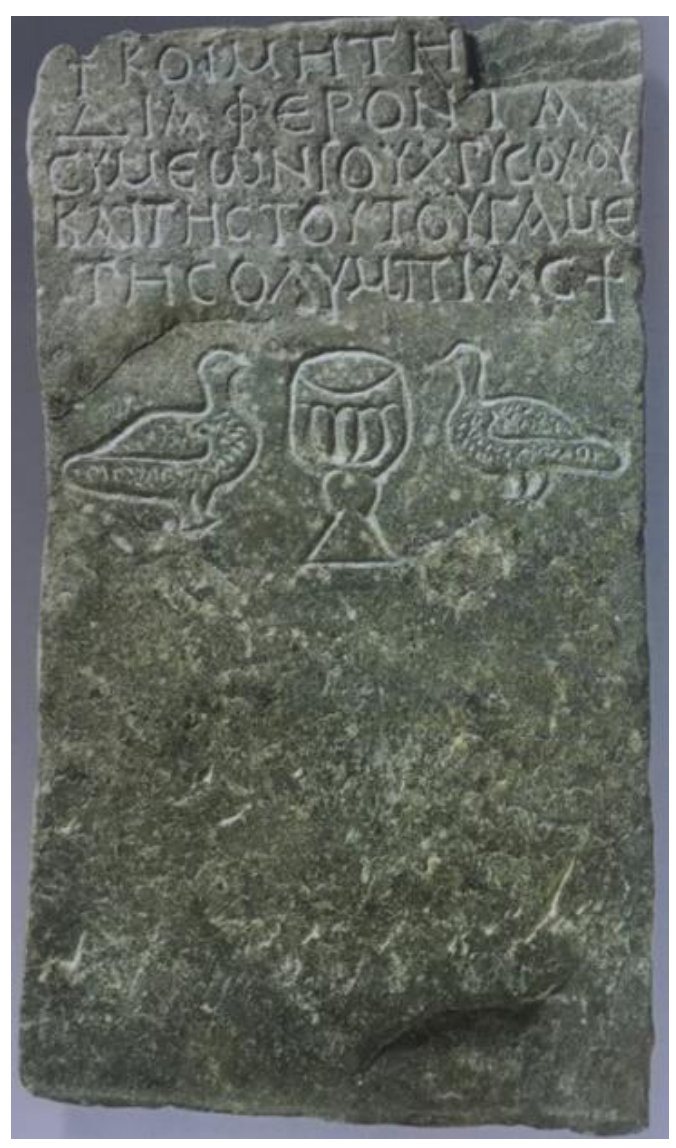

Resim 21: Ravenna Quadrarco di Braccioforte, Eliseo Profeta'nın Lahdi ${ }^{73}$

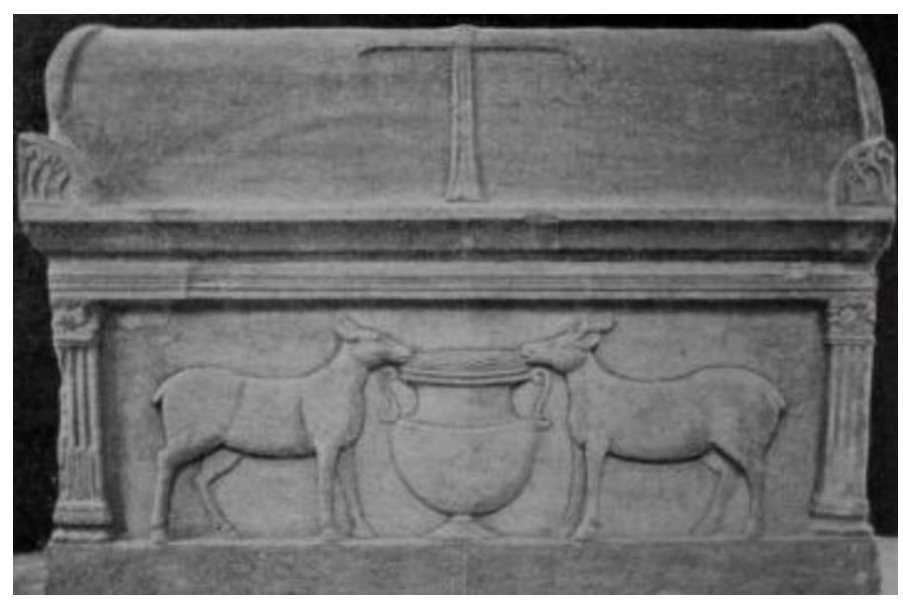

${ }^{73}$ https://i.pinimg.com/474x/51/05/af/5105af0f7ebeb805a85a64c89d3777df.jpg Erişim Adresi: 06.01.2020 
Resim 22: Koyunoğlu Müzesi, Ambon Merdiven Yan Levhası (Temple, 2013)

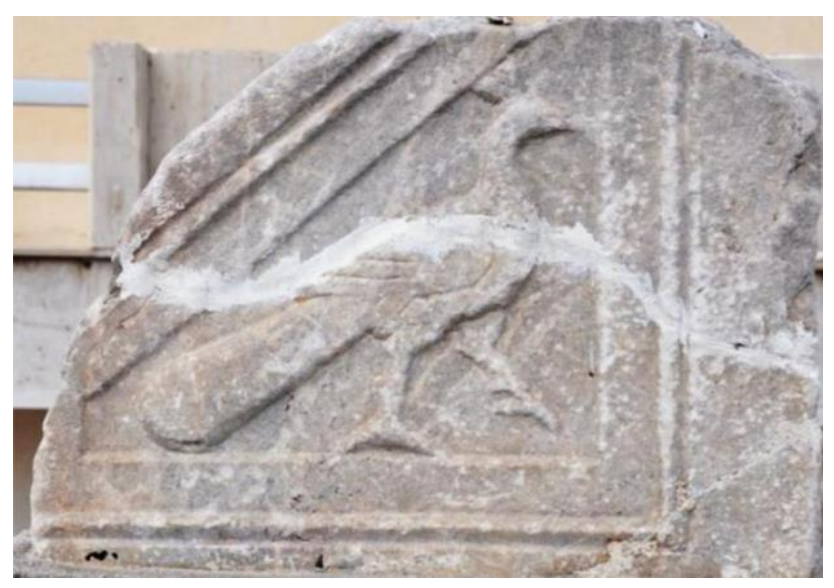

Resim 23: Ankara Anadolu Medeniyetleri Müzesi, Levha (Aydın, 2002)

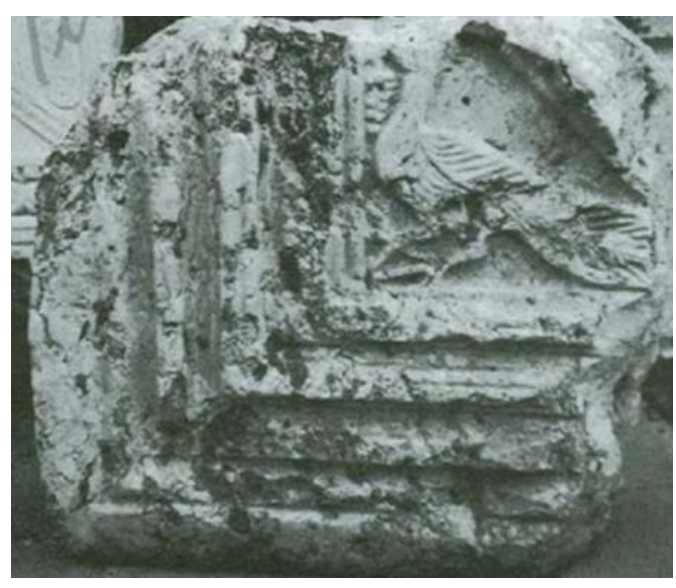

Resim 24: Afyon Arkeoloji Müzesi, Ambon Yan Levhaları (Parman, 2002)

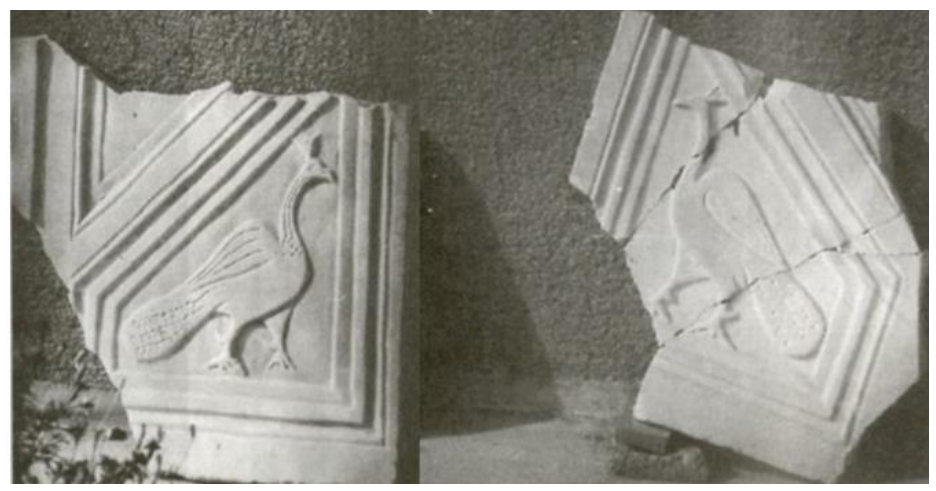


Resim 25: Milas Müzesi, Ambon Yan Levhası A Yüzü ${ }^{74}$

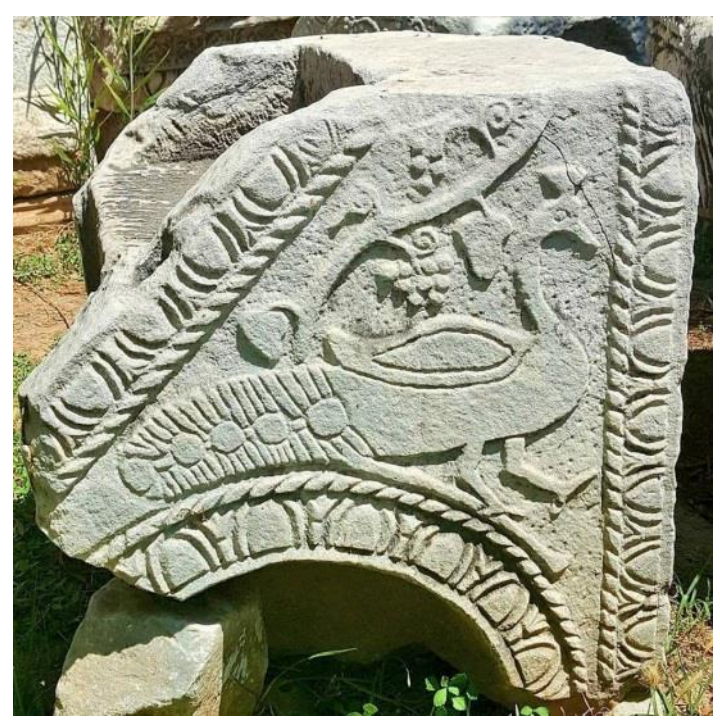

Resim 26: Brescia S. Salvatore Müzesi, Ambon veya Kiborium frizi ${ }^{75}$

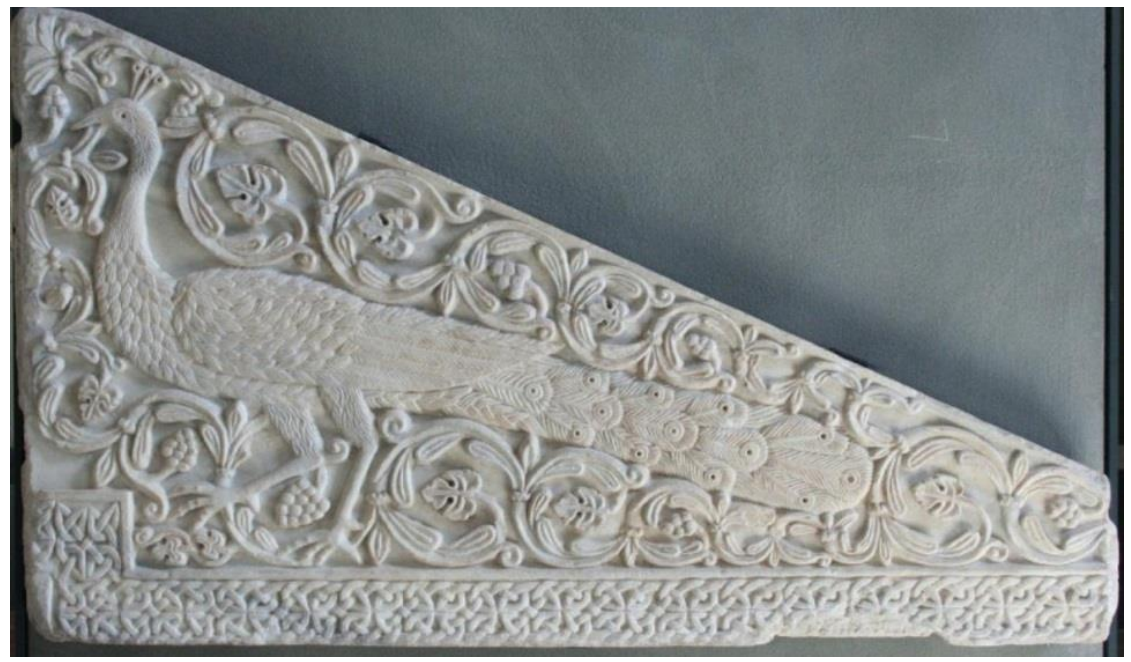

\footnotetext{
${ }^{74}$ https://tr.pinterest.com/pin/582653270513934157/ Erişim Tarihi: (20.12.2017)

${ }^{75}$ https://encryptedtbn0.gstatic.com/images?q=tbn:ANd9GcTePf390S_i8hbgwefCNHhgG6KSPGKmsacVimF1n9ITyIH KAC9 Erişim Tarihi: (20.12.2017)
} 
Resim 27: Afyon Arkeoloji Müzesi, Ambon Yan Levhasi ${ }^{76}$

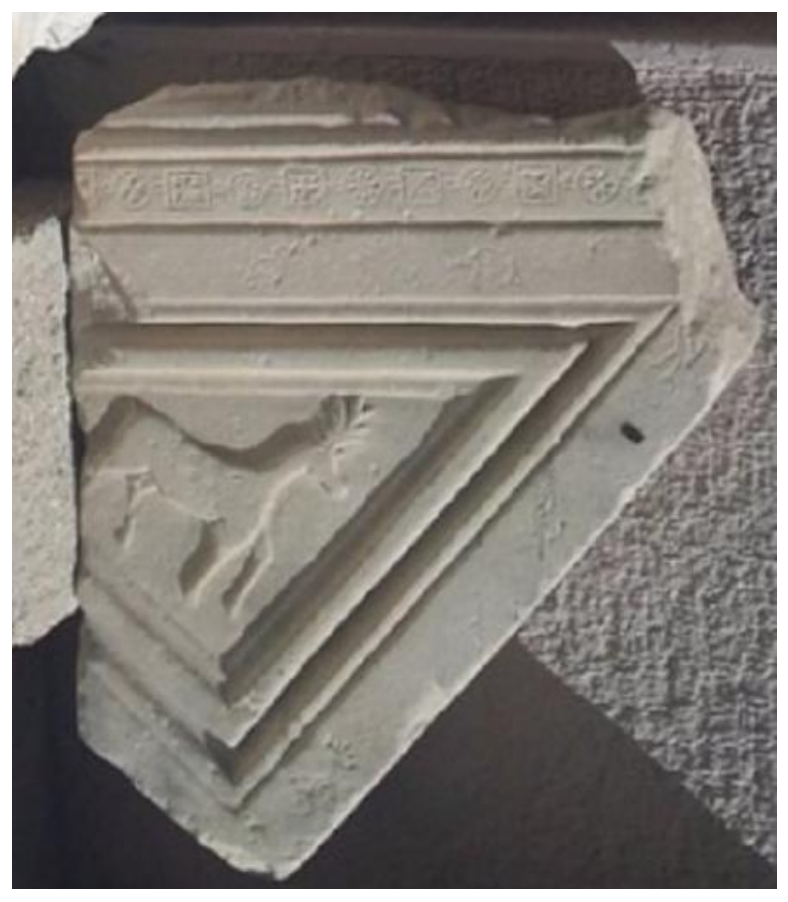

Resim 28: Kütahya Müzesi, Ambon Yan Levhasi ${ }^{77}$

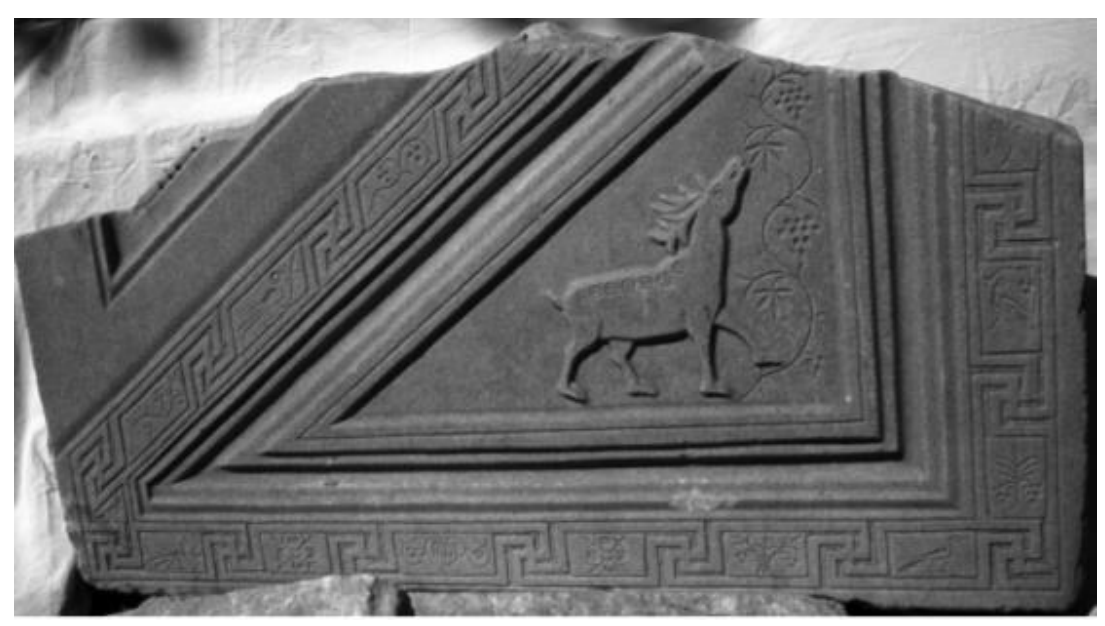

76 https://www.tripadvisor.com.tr/Attraction_Review-g609051-d3601286-Reviews-Afyonkarahisar_MuseumAfyonkarahisar_Afyonkarahisar_District_Afyonkarahisar_Provi.html\#photos;aggregationId=101\&albumid=101\&filter= $7 \& \mathrm{ff}=221542189$ Erişim Tarihi: $(06.01 .2020)$

${ }^{77}$ Philipp Niewöhner, "Phrygian marble and stonemasonry as markers of regional distinctiveness in Late Antiquity" in P. Thonemann (Ed.), Roman Phrygia: Culture and Society (Greek Culture in the Roman World, Cambridge: Cambridge University Press, 2013, s.244, fig.10.23. 
Resim 29: Çanakkale Arkeoloji Müzesi, Levha ${ }^{78}$

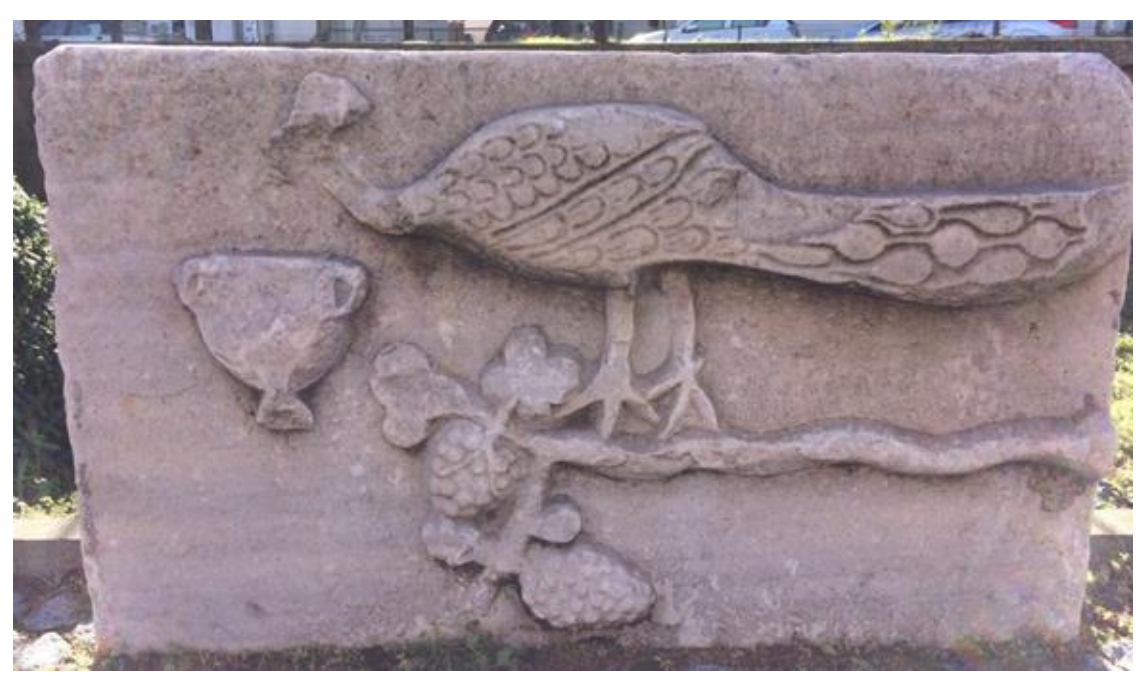

Resim 30: İzmir Arkeoloji Müzesi,Levha (Anabolu, 1988)

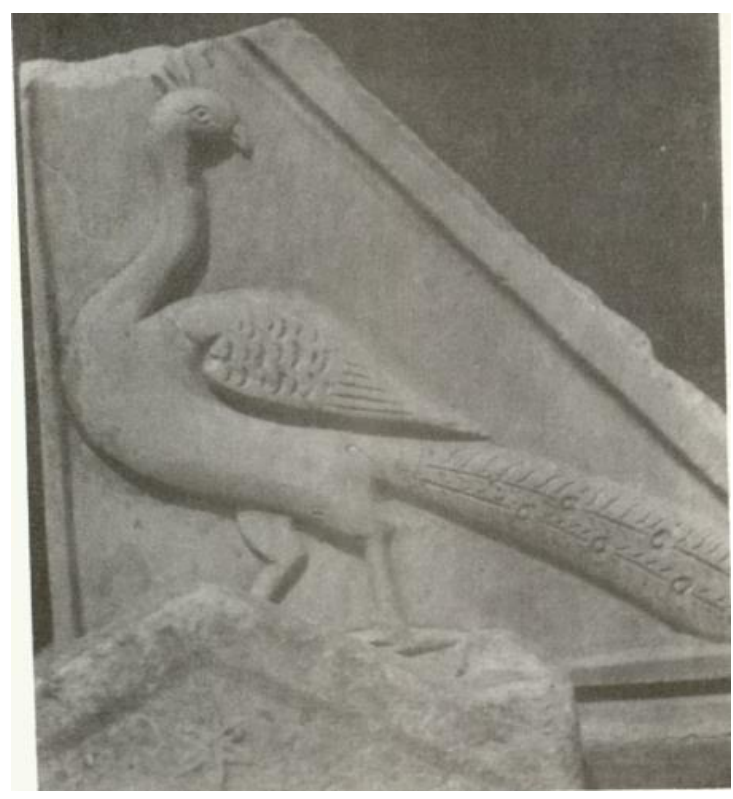

${ }^{78}$ Fotoğraf tarafımca çekilmiştir. 
Resim 31: Argos Müzesi, Levha (Grabar, 1976)

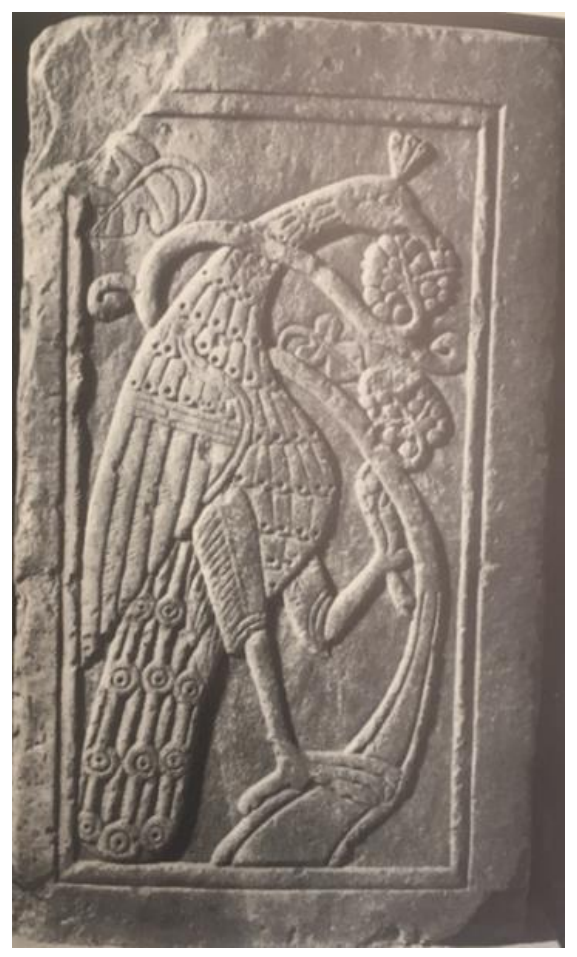

Resim 32: Üsküp Arkeoloji Müzesi, Ambon Levhasi ${ }^{79}$

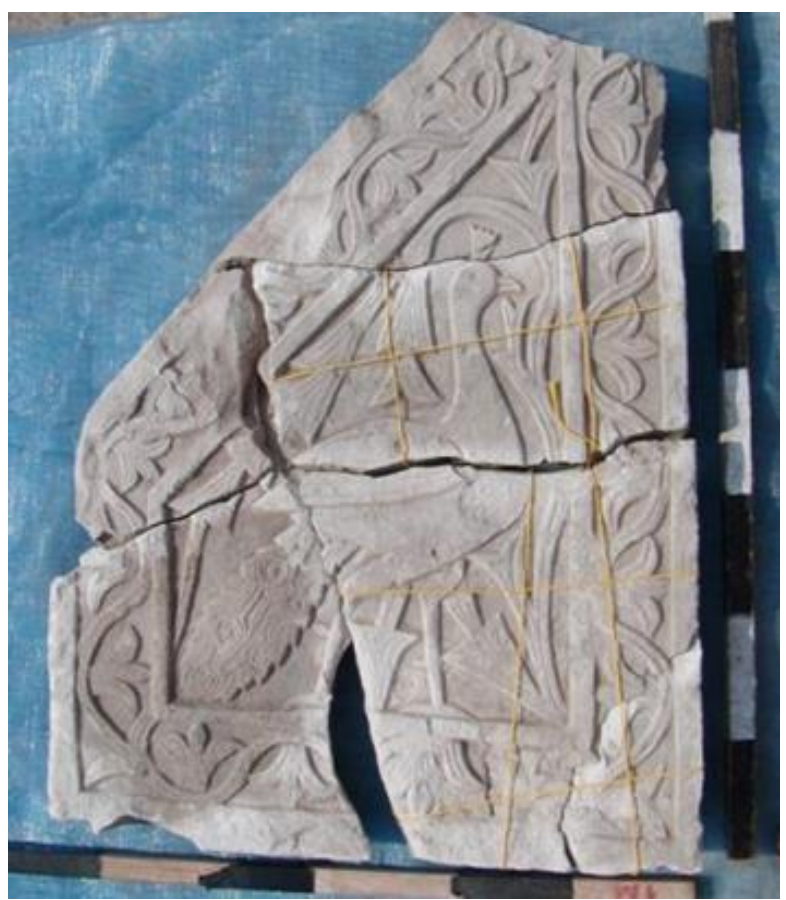

${ }^{79} \mathrm{http}$ //www.doaks.org/research/support-for-research/project-grants/reports/2009-

2010/images/Konjuh\%2009\%20rpt_Page_16_Image_0002.jpg/view Erişim Tarihi: (06.01.2020) 
Resim 33: St. Domitilla Katakompu, mezar taşs ${ }^{80}$

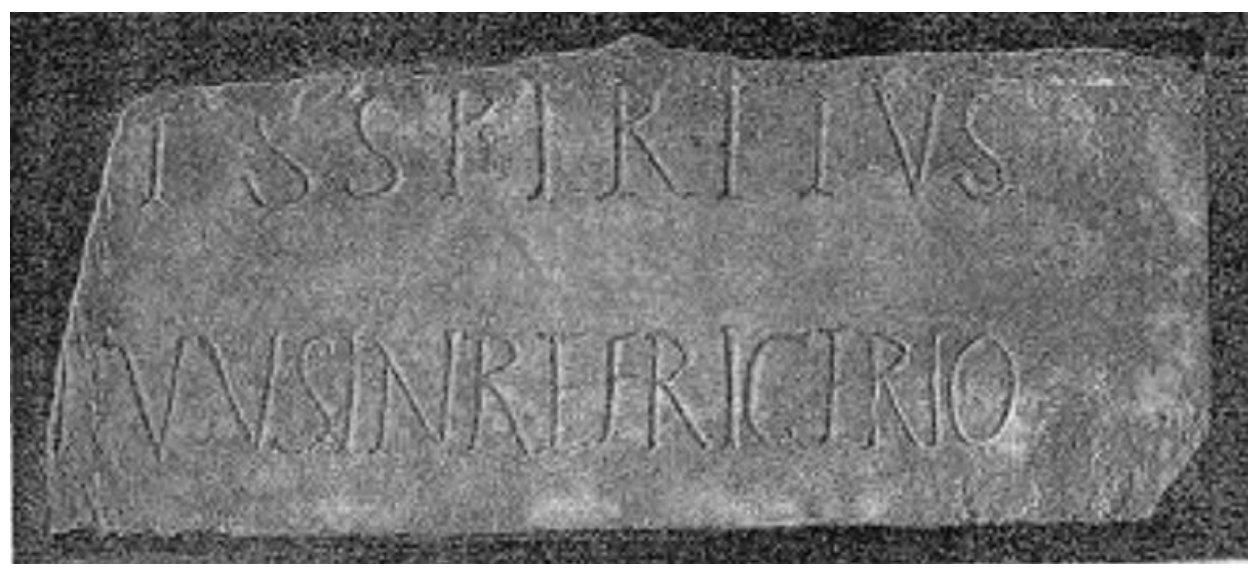

Resim 34: Roma St. Calixto Katakompu, Fresko ${ }^{81}$

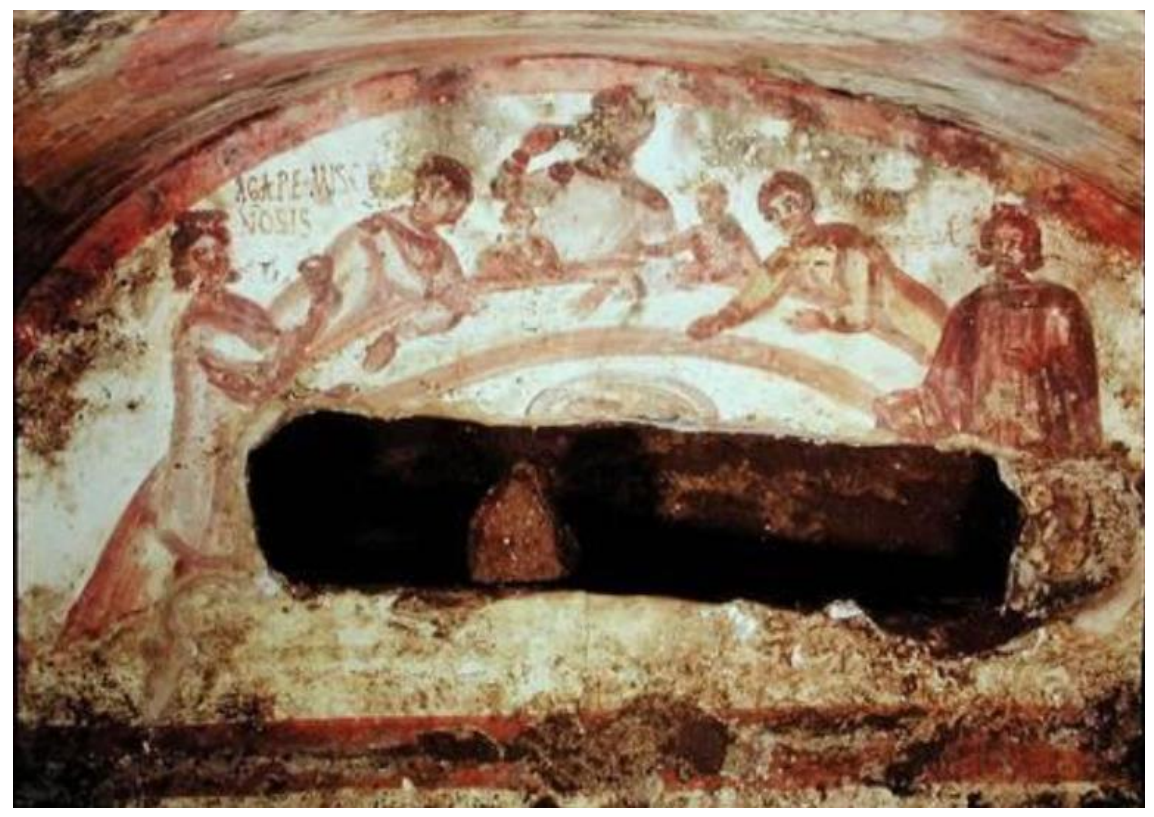

${ }^{80} \mathrm{https}: / /$ avvenimentiestoria.forumfree.it/?t=75685128 Erişim Tarihi: $(03.01 .2020)$

${ }^{81} \mathrm{https} / / /$ www.myartprints.com/kunst/paleo_christian/woman_presiding_refrigerium_hi.jpg Erişim Tarihi: (03.01.2020) 
Resim 35: Roma Priscilla Katakombu, Fresko ${ }^{82}$

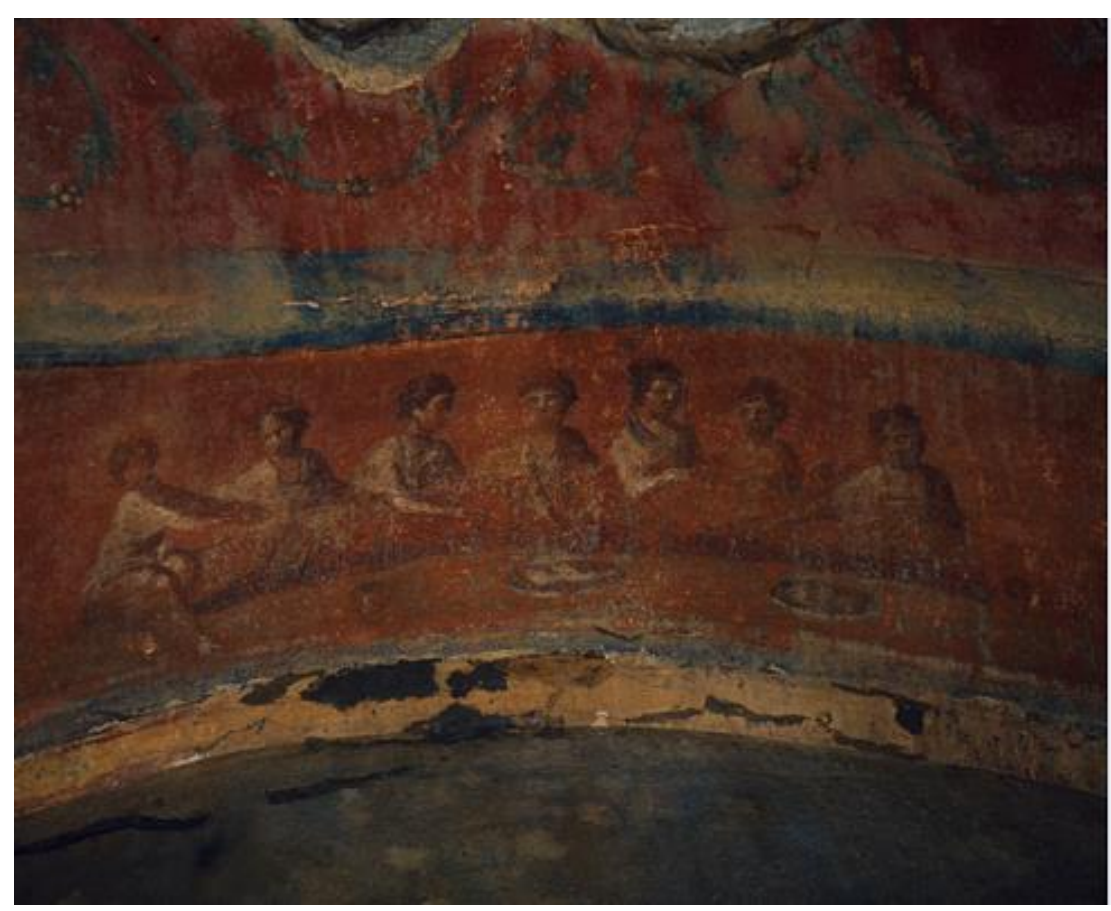

${ }^{82}$ https://repository.westernsem.edu/xmlui/handle/1866/689 Erişim Tarihi: (03.01.2020) 